\section{B}

A BWXT/Bechtel Enterprise

\section{Y-12}

NATIONAL SECURITY COMPLEX
GROUNDWATER PROTECTION PROGRAM MANAGEMENT PLAN

FOR THE U.S. DEPARTMENT OF ENERGY Y_12 NATIONAL SECURITY COMPLEX, OAK RIDGE, TENNESSEE

Revision 1

Issue Date: March 2004

Prepared by

ELVADO ENVIRONMENTAL LLC Under Subcontract No. 4300012529

and the

Environmental Compliance Department Environment, Safety, and Health Division Y_12 National Security Complex Oak Ridge, Tennessee 37831

Managed by

BWXT Y-12 L.L.C.

for the U.S. Department of Energy National Nuclear Security Administration Under Contract No. DE-AC05-00OR22800 


\section{DISCLAIMER}

This report was prepared as an account of work sponsored by an agency of the United States Government. Neither the United States Government nor any agency thereof, nor any of their employees, makes any warranty, express or implied, or assumes any legal liability or responsibility for the accuracy, completeness, or usefulness of any information, apparatus, product, or process disclosed, or represents that its use would not infringe privately owned rights. Reference herein to any specific commercial product, process, or service by trade name, trademark, manufacturer, or otherwise, does not necessarily constitute or imply its endorsement, recommendation, or favoring of the United States Government or any agency thereof. The views and opinions of authors expressed herein do not necessarily state or reflect those of the United States Government or any agency thereof. 


\title{
GROUNDWATER PROTECTION PROGRAM MANAGEMENT PLAN \\ FOR THE U.S. DEPARTMENT OF ENERGY Y-12 NATIONAL SECURITY COMPLEX, OAK RIDGE, TENNESSEE Revision 1
}

Issue Date: March 2004

\author{
Prepared by \\ ELVADO ENVIRONMENTAL LLC \\ Under Subcontract No. 4300012529 \\ and the \\ Environmental Compliance Department \\ Environment, Safety, and Health Division \\ Y-12 National Security Complex \\ Oak Ridge, Tennessee 37831
}

Managed by

BWXT Y-12, L.L.C.

for the U.S. Department of Energy

National Nuclear Security Administration

Under Contract No. DE-AC05-00OR22800 


\section{CONTENTS}

$\underline{\text { Page }}$

FIGURES $\ldots \ldots \ldots \ldots \ldots \ldots \ldots \ldots \ldots \ldots \ldots \ldots \ldots \ldots \ldots \ldots \ldots$ ii

ACRONYMS AND ABBREVIATIONS $\ldots \ldots \ldots \ldots \ldots \ldots \ldots \ldots \ldots \ldots \ldots \ldots \ldots$ iii

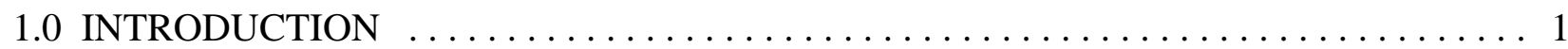

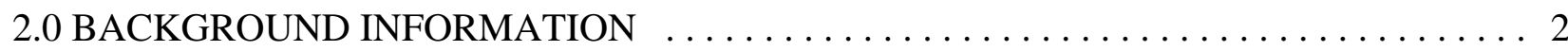

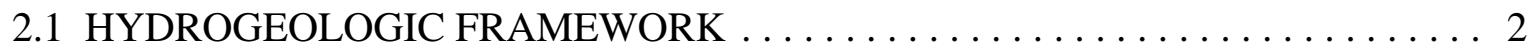

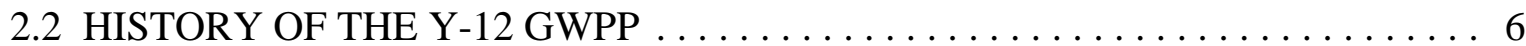

2.3 ONGOING GROUNDWATER MONITORING ACTIVITIES AT Y-12 . . . 13

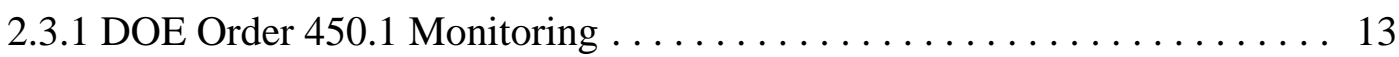

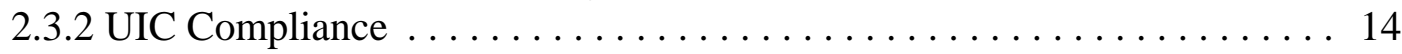

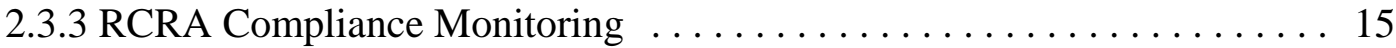

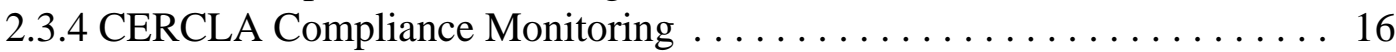

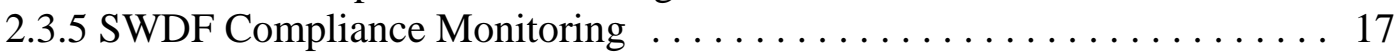

2.3.6 Groundwater Elevation Monitoring $\ldots \ldots \ldots \ldots \ldots \ldots \ldots \ldots$

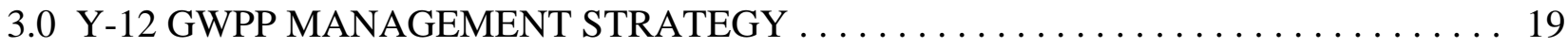

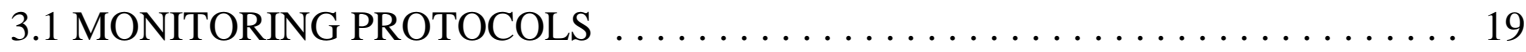

3.1.1 Annual Sampling and Analysis Planning . . . . . . . . . . . . . . 19

3.1.2 Semiannual Sampling Frequency . . . . . . . . . . . . . . . . 19

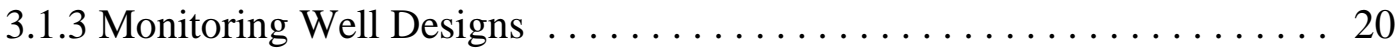

3.1.4 Sampling Procedures and Analytical Methods .............. 20

3.1.5 Data Quality Objective Screening ................... 20

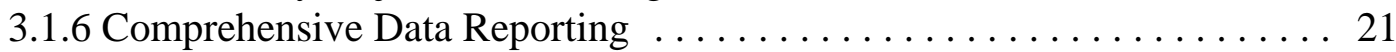

3.2 MONITORING SYSTEM STEWARDSHIP $\ldots \ldots \ldots \ldots \ldots \ldots \ldots \ldots \ldots \ldots \ldots$

3.3 MONITORING ORGANIZATION INTERACTION $\ldots \ldots \ldots \ldots \ldots \ldots \ldots \ldots \ldots .22$

3.4 MONITORING INNOVATION AND IMPROVEMENT $\ldots \ldots \ldots \ldots \ldots \ldots \ldots 22$

4.0 Y-12 GWPP ORGANIZATION, ROLES, AND RESPONSIBILITIES $\ldots \ldots \ldots \ldots \ldots$

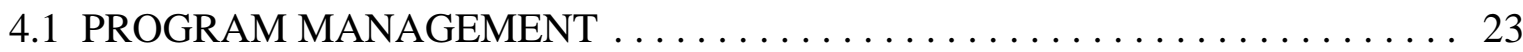

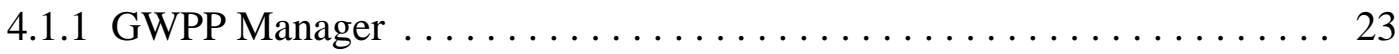

4.1.2 GWPP Sampling and Analysis Coordinator $\ldots \ldots \ldots \ldots \ldots \ldots \ldots$

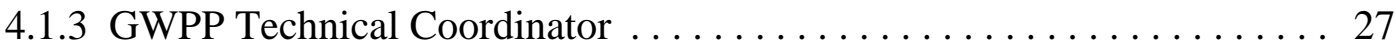

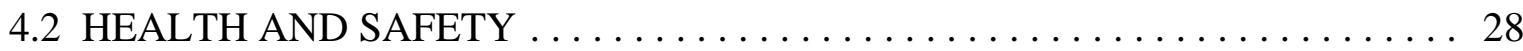

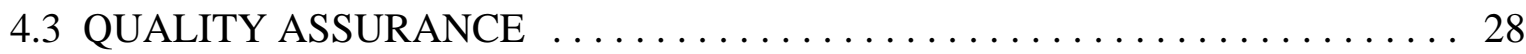

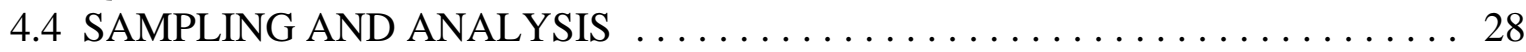

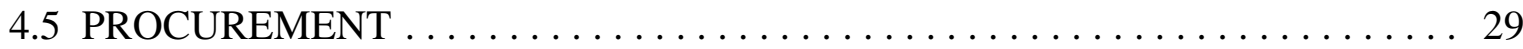

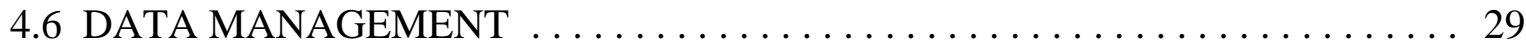

4.7 DATA VALIDATION AND EVALUATION $\ldots \ldots \ldots \ldots \ldots \ldots \ldots \ldots \ldots \ldots$

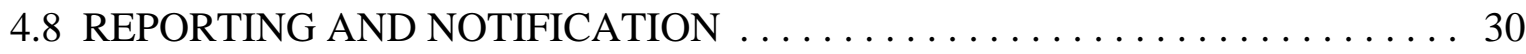

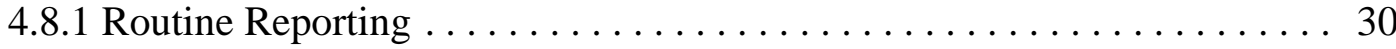

4.8.1.1 Groundwater Monitoring Data Reports . . . . . . . . . . . 30

4.8.1.2 Monitoring Data Evaluation Compendium . . . . . . . . . 31 
4.8.1.3 Oak Ridge Reservation Annual Site Environmental Report . . . 31

4.8.1.4 Well Inspection and Maintenance Reports . . . . . . . . . . 31

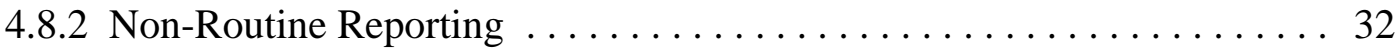

4.9 RECORDKEEPING AND DOCUMENT CONTROL $\ldots \ldots \ldots \ldots \ldots \ldots \ldots \ldots 32$

4.10 HYDROGEOLOGICAL INTERPRETATION $\ldots \ldots \ldots \ldots \ldots \ldots \ldots \ldots \ldots . \ldots \ldots$

4.11 ENGINEERING AND WELL INSTALLATION $\ldots \ldots \ldots \ldots \ldots \ldots \ldots \ldots$

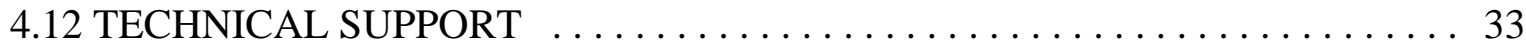

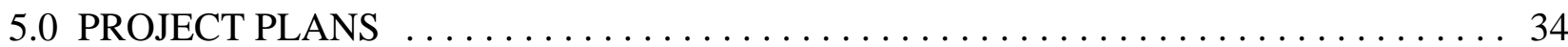

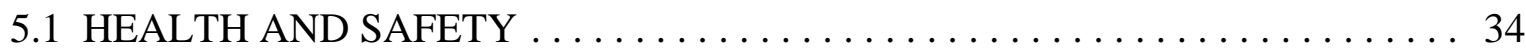

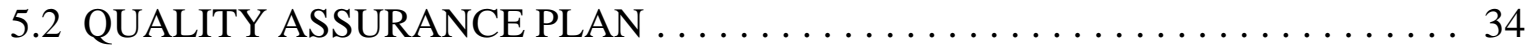

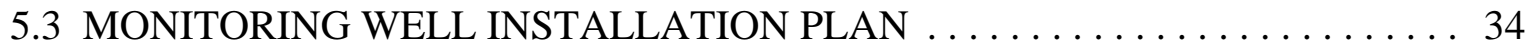

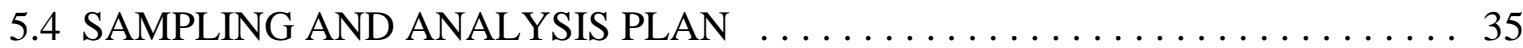

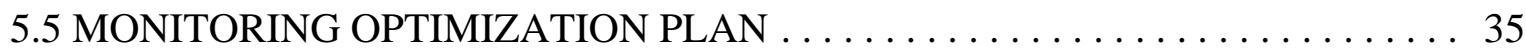

5.6 LABORATORY QUALITY ASSURANCE PLAN $\ldots \ldots \ldots \ldots \ldots \ldots \ldots \ldots$

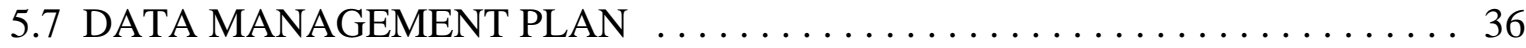

5.8 WELL PLUGGING AND ABANDONMENT PLAN $\ldots \ldots \ldots \ldots \ldots \ldots \ldots \ldots$

5.9 WELL INSPECTION AND MAINTENANCE PLAN $\ldots \ldots \ldots \ldots \ldots \ldots \ldots$

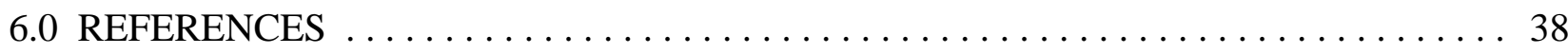

\section{FIGURES}

\section{$\underline{\text { Page }}$}

1 Hydrogeologic regimes at the $\mathrm{Y}-12$ National Security Complex $\ldots \ldots \ldots \ldots$

2 Bedrock geology in the vicinity of the Y-12 National Security Complex ........4

3 Locations of principal waste management sites at the Y-12 National Security Complex . 7

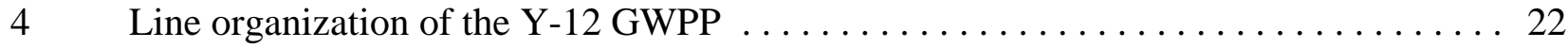

5 Matrix organization of the Y-12 GWPP $\ldots \ldots \ldots \ldots \ldots \ldots \ldots \ldots \ldots \ldots \ldots$ 


\section{ACRONYMS AND ABBREVIATIONS}

\begin{tabular}{|c|c|}
\hline ADMS & Analytical Data Management System \\
\hline $\mathrm{ACO}$ & Analytical Chemistry Organization \\
\hline BCBG & Bear Creek Burial Grounds \\
\hline Bear Creek Regime & Bear Creek Hydrogeologic Regime \\
\hline $\mathrm{BCV}$ & Bear Creek Valley \\
\hline bgs & below ground surface \\
\hline BJC & Bechtel Jacobs Company, L.L.C. \\
\hline BWXT & BWXT Y-12, L.L.C. \\
\hline $\mathrm{CA}$ & characterization area \\
\hline CERCLA & Comprehensive Environmental Response, Compensation, and Liability Act \\
\hline Chestnut Ridge Regime & Chestnut Ridge Hydrogeologic Regime \\
\hline CRSDB & Chestnut Ridge Sediment Disposal Basin \\
\hline CRSP & Chestnut Ridge Security Pits \\
\hline CY & calendar year \\
\hline DOE & United States Department of Energy \\
\hline DQO & data quality objective \\
\hline East Fork Regime & Upper East Fork Poplar Creek Hydrogeologic Regime \\
\hline ECD & Environmental Compliance Department \\
\hline EMP & Environmental Monitoring Plan \\
\hline EMS & environmental management system \\
\hline EMWMF & Environmental Management Waste Management Facility \\
\hline EPA & United States Environmental Protection Agency \\
\hline ES\&H & Environment, Safety, and Health (Division) \\
\hline FCAP & Filled Coal Ash Pond \\
\hline FFA & Federal Facility Agreement \\
\hline FS & feasibility study \\
\hline $\mathrm{ft}$ & feet \\
\hline GIMS & Groundwater Information Management System \\
\hline GWDER & Groundwater Data Evaluation Report \\
\hline GWMR & Groundwater Data Monitoring Report \\
\hline GWPP & Groundwater Protection Program \\
\hline GWPS & Groundwater Protection Standard \\
\hline ISMS & Integrated Safety Management System \\
\hline IWQP & Integrated Water Quality Program \\
\hline KHQ & Kerr Hollow Quarry \\
\hline LMES & Lockheed Martin Energy Systems, Inc. \\
\hline $\mathrm{M} \& \mathrm{O}$ & management and operation \\
\hline MDEC & Monitoring Data Evaluation Compendium \\
\hline MOP & Monitoring Optimization Plan \\
\hline MOU & Memorandum of Understanding \\
\hline OREIS & Oak Ridge Environmental Information System \\
\hline ORNL & Oak Ridge National Laboratory \\
\hline ORR & Oak Ridge Reservation \\
\hline OU & operable unit \\
\hline
\end{tabular}




\section{ACRONYMS AND ABBREVIATIONS (continued)}

$\begin{array}{ll}\text { P\&A } & \text { plugging and abandonment } \\ \text { PCP } & \text { post-closure permit } \\ \text { POC } & \text { point of compliance } \\ \text { QA } & \text { quality assurance } \\ \text { QC } & \text { quality control } \\ \text { QAP } & \text { Quality Assurance Plan } \\ \text { QPP } & \text { Quality Program Plan } \\ \text { RCRA } & \text { Resource Conservation and Recovery Act } \\ \text { RI } & \text { remedial investigation } \\ \text { ROD } & \text { record of decision } \\ \text { SAIC } & \text { Science Applications International Corporation } \\ \text { SAP } & \text { Sampling and Analysis Plan } \\ \text { S/RID } & \text { Standard/Requirement Identification Document } \\ \text { SWDF } & \text { Solid Waste Disposal Facility (nonhazardous waste) } \\ \text { TDEC } & \text { Tennessee Department of Environment and Conservation } \\ \text { TSD } & \text { treatment, storage, and disposal } \\ \text { UIC } & \text { underground injection control } \\ \text { UNCS } & \text { United Nuclear Corporation Site } \\ \text { USGS } & \text { United States Geological Survey } \\ \text { VOC } & \text { Volatile Organic Compound } \\ \text { WRRP } & \text { Water Resources Restoration Program } \\ \text { Y-12 } & \text { Y-12 National Security Complex }\end{array}$




\subsection{INTRODUCTION}

This document presents the Groundwater Protection Program (GWPP) management plan for the U.S. Department of Energy (DOE) Y-12 National Security Complex (hereafter referenced as Y-12). The Y-12 GWPP functions as the primary point-of-contact for groundwater-related issues at Y-12, provides stewardship of the extensive network of groundwater monitoring wells at Y-12, and serves as a resource for technical expertise, support, and historical data for groundwater-related activities at $\mathrm{Y}-12$. These organizational functions each serve the primary programmatic purpose of the GWPP, which is to ensure that groundwater monitoring activities within areas under Y-12 administrative control provide representative data in compliance with the multiple purposes of applicable state and federal regulations, DOE orders, and the corporate policies of BWXT Y-12, L.L.C. (hereafter referenced as BWXT), the Y-12 management and operations (M\&O) contractor for DOE.

This GWPP management plan addresses the requirements of DOE Order 450.1 (BWXT Y12 S/RID) regarding the implementation of a site-wide approach for groundwater protection at each DOE facility. Additionally, this plan is a "living" document that is reviewed annually, revised and reissued every three years, and is formatted to provide for updating individual sections independent of the rest of the document. Section 2 includes a short description of the groundwater system at Y-12, the history of groundwater monitoring at Y-12 and the corresponding evolution of the GWPP, and an overview of ongoing Y-12 groundwater monitoring activities. Section 3 describes the key elements of the GWPP management strategy. Organizational roles and responsibilities of GWPP personnel are outlined in Section 4. Section 5 presents an overview of the GWPP project plans for applicable programmatic elements. Section 6 lists the reports, plans, and documents that are referenced for technical and administrative details. 


\subsection{BACKGROUND INFORMATION}

The area under Y-12 administrative control is divided into three hydrogeologic regimes for the purposes of groundwater monitoring (Figure 1). The Bear Creek Hydrogeologic Regime (Bear Creek Regime) encompasses a section of Bear Creek Valley (BCV) between the west end of Y-12 and the west end of the valley at State Route 95 (directions are in reference to the Y-12 grid system). The Upper East Fork Poplar Creek Hydrogeologic Regime (East Fork Regime) encompasses industrial facilities and support structures located between Scarboro Road at the east end of Y-12 and Old Bear Creek Road at the west end of Y-12. The Chestnut Ridge Hydrogeologic Regime (Chestnut Ridge Regime) encompasses a section of Chestnut Ridge west of Scarboro Road and east of Dunaway Branch southwest of Y-12. The following sections provide background information regarding the groundwater system at Y-12, the history of groundwater quality monitoring in each hydrogeologic regime, and the status of ongoing groundwater monitoring activities. This information establishes the framework underlying the GWPP management strategy described in Section 3.

\subsection{HYDROGEOLOGIC FRAMEWORK}

The following discussion provides a generalized overview of the complex hydrogeologic system at Y-12.

The geology in the vicinity of Y-12 is generally characterized by sequences of southeast-dipping, fractured clastic (primarily shale and siltstone) and carbonate (limestone and dolostone) strata of Lower Cambrian to Lower Ordovician age (Figure 2). Strike and dip of bedding is generally $\mathrm{N} 55^{\circ} \mathrm{E}$ and $45^{\circ} \mathrm{SE}$, respectively. $\mathrm{BCV}$ is underlain by the interbedded limestone and shale formations of the Conasauga Group (Figure 2). The Maynardville Limestone, the uppermost formation of the Conasauga Group, subcrops along the axis of BCV at the base of Chestnut Ridge and the underlying formations of the Conasauga Group, (the Nolichucky Shale, Maryville Limestone, Rogersville Shale, Rutledge Limestone, and Pumpkin Valley Shale) subcrop successively to the north toward Pine Ridge (Figure 2). Shale and siltstone beds of the underlying Rome Formation from Pine Ridge to the north, and the primarily dolostone strata of the overlying Knox Group from Chestnut Ridge to the south (Figure 2).

Bedrock near Y-12 area is overlain by any of several materials, including alluvium, colluvium, manmade fill, fine-grained residuum from the weathering of the bedrock, saprolite (a transitional mixture of fine residuum and bedrock remnants), and weathered bedrock. In many areas, the saprolite retains primary textural features of the bedrock, including fractures.

The most pervasive bedrock structural features near Y-12 are extensional, hybrid, and shear fractures. Three major joint sets are generally evident, one that roughly parallels strike and dip of bedding, one steeply dipping set that parallels geologic strike but is perpendicular to dip, and one steeply dipping set that trends perpendicular to strike. Fracture densities ranging from about 1 to 60 per foot (ft) have been observed in rock outcrops near the Oak Ridge National Laboratory (ORNL), and most fractures are short, ranging from tenths of an inch to a few feet in length. Within a fracture, groundwater may flow either downdip, laterally, or in both directions. Changes in flow 


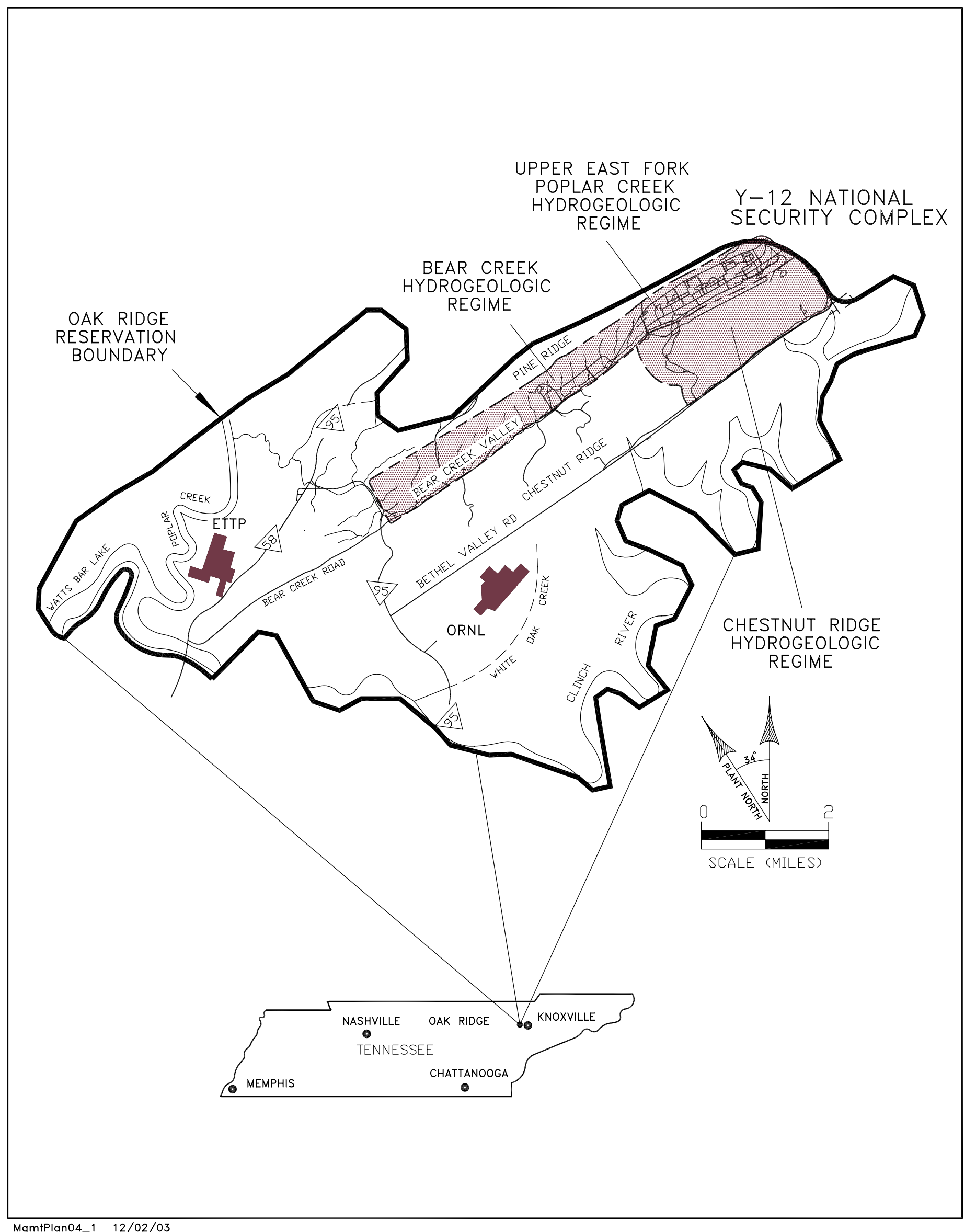

Fig. 1. Hydrogeologic regimes at the Y-12 National Security Complex. 


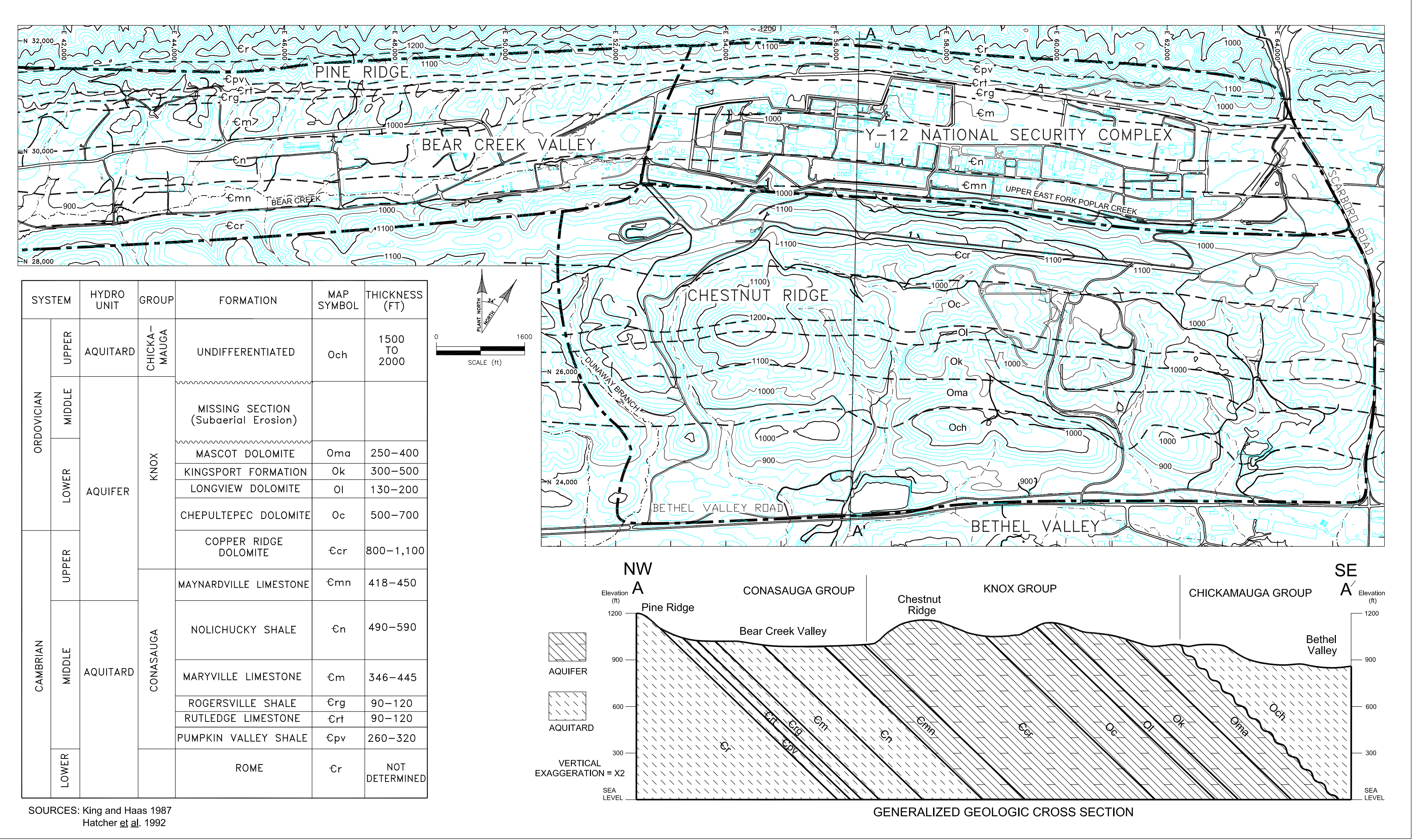

MgmtPlan04 2 12/02/03 
direction may occur at fracture splits, truncations, and intersections and groundwater flow paths may locally resemble stairsteps in both plan and sectional views. Dissolution of carbonates along fractures, particularly in the Maynardville Limestone and the Knox Group, has produced solutionenlarged features ranging from less than an inch to tens of feet in diameter. Solution cavities occur throughout the Maynardville Limestone, but most frequently in two of six stratigraphic zones, one at the top and one at the bottom of the formation.

In the Y-12 vicinity, the Rome Formation, Conasauga Group, and Knox Group comprise two basic hydrogeologic units: (1) an aquifer, designated the Knox Aquifer, consisting of the Maynardville Limestone and the overlying formations of the Knox Group, and (2) the aquitard, consisting of the Nolichucky Shale, Maryville Limestone, Rogersville Shale, Rutledge Limestone, Pumpkin Valley Shale of the Conasauga Group, and the Rome Formation (Figure 2). The aquifer formations floor the valley along the axis of BCV (Maynardville Limestone) and form Chestnut Ridge. The aquitard formations are partially exposed successively to the north toward Pine Ridge (Figure 2). The aquitard, which underlies the primary contaminant source areas in the Bear Creek Regime and the East Fork Regime, is hydraulically upgradient of the Maynardville Limestone, which functions as a hydrologic drain in BCV and provides the principal avenues for contaminant transport. Groundwater flow in the aquitard is dominated by fractures. Groundwater flow in the aquifer has components of both fracture flow and flow through solution-enlarged cavities and conduits. Flow through the porous rock matrix is negligible in both units; however, bedrock matrix porosity is an important factor regarding contaminant migration because of matrix diffusion processes.

A high conductivity interval near the bedrock/residuum interface (the water table interval) is where nearly all groundwater flow occurs in the aquitard. Below the water table interval, flow is most active at depths less than $100 \mathrm{ft}$ below ground surface (bgs); however, contaminants in groundwater more than $200 \mathrm{ft}$ bgs in the Nolichucky Shale clearly indicate permeable flowpaths at depth. Flow occurs in response to precipitation when flowpaths in the residual soils become saturated and rapidly transmit water laterally (stormflow) down slope toward springs and seeps in drainage features, and vertically to the water table interval. Inflow into the water table interval promotes strike-parallel flow toward discharge areas in nearby cross-cutting streams. Only a small percentage of total flow recharges to the deeper bedrock, where upward hydraulic gradients predominate. In the East Fork Regime the stormflow zone has been extensively altered by cut and fill construction. Tributaries to UEFPC were captured in a storm drain network. This network along with other utilities provide preferential flow pathways throughout the area.

Most groundwater flow in the aquifer occurs at shallow depths (i.e., <100 ft bgs) in an extensively interconnected maze of solution conduits and cavities (karst network). Below the shallow karst network, fractures provide the primary flowpaths. In BCV, groundwater in the aquifer flows primarily along strike, parallel to the axis of the valley. Flow in the shallow karst network is relatively rapid, and during rainfall, occurs as quickflow discharge to Bear Creek and UEFPC. Active groundwater circulation occurs at greater depth in the aquifer than in the aquitard, and in $\mathrm{BCV}$, groundwater from the deeper flow system discharges along major gaining (influent) reaches of Bear Creek channel. These discharge areas are probably related to large-scale structural features (e.g., cross-strike faults) or stratigraphic discontinuities in the Maynardville Limestone.

The overall pattern of groundwater flow in the aquifer on Chestnut Ridge is from the recharge areas on the ridge crest toward discharge areas that include the Maynardville Limestone in BCV, and 
springs and seeps in the crosscutting tributaries along the northern and southern flanks of the ridge. Potentiometric data and contaminant plume configurations also indicate a substantial stike-parallel flow component along the axis of the ridge.

\subsection{HISTORY OF THE Y-12 GWPP}

The GWPP at Y-12 evolved from early groundwater monitoring efforts that began in 1975 and expanded through the early 1980s. Groundwater monitoring during this period was primarily directed toward site-specific characterization objectives for the primary waste management sites associated with Y-12 (Figure 3). Monitoring activities were coordinated by the Y-12 Health, Safety, Environment, and Accountability Organization without a formal programmatic plan. The following chronology provides details regarding the history of groundwater monitoring at Y-12 and the formal establishment of the GWPP.

\section{5 - 1982}

Groundwater quality monitoring at Y-12 began in 1975 when periodic sampling of pre-existing monitoring wells was initiated to determine groundwater quality in and around waste disposal sites located in the BCV west of Y-12 (Pritz 1983). Beginning in 1981 and continuing through 1982, these initial monitoring activities expanded to include annual, biannual, or quarterly sampling of additional monitoring wells in BCV and on Chestnut Ridge south of Y-12 (Law Engineering 1983). During this period, several groundwater investigations also were completed for engineering and construction site investigations. These included an investigation initiated before 1975 by the United States Geological Survey (USGS) that involved the installation of groundwater wells at several locations throughout BCV.

\section{3 - 1985}

As a result of information obtained by officials of the Tennessee Department of Environment and Conservation (TDEC), formerly the Tennessee Department of Health and Environment, during an inspection of the past and present waste disposal practices at $\mathrm{Y}-12$, representatives of DOE, the TDEC, and the U. S. Environmental Protection Agency (EPA) signed a Memorandum of Understanding (MOU) on May 26, 1983. Item X of the MOU required an investigation of hydrogeologic conditions at Y-12, and preliminary investigations were initiated in 1983 at several waste management sites, including the Chestnut Ridge Sediment Disposal Basin (CRSDB), the S-3 Site (formerly the S-3 Ponds), the Oil Landfarm, and the Bear Creek Burial Grounds (BCBG) (Figure 3). A report containing results of groundwater sampling, pumping tests, geological investigations, and recommendations for future studies and groundwater monitoring activities was issued later that year (Law Engineering 1983). Item XI of the MOU required preparation of a comprehensive monitoring plan for groundwater and surface water at Y-12, including sampling locations and monitored parameters. In response, a master plan for groundwater and surface-water monitoring at Y-12 was developed and implemented (Pritz 1983). Monitoring under this plan included a network of wells located at waste management sites located in BCV and on Chestnut Ridge. Analytical parameters and sampling frequencies varied from site to site, depending in part on the quantities and types of wastes disposed of at the various sites.

An investigation to determine the extent of mercury contamination in soils and groundwater within Y-12 also was initiated in 1983 after DOE released a report containing preliminary information on 


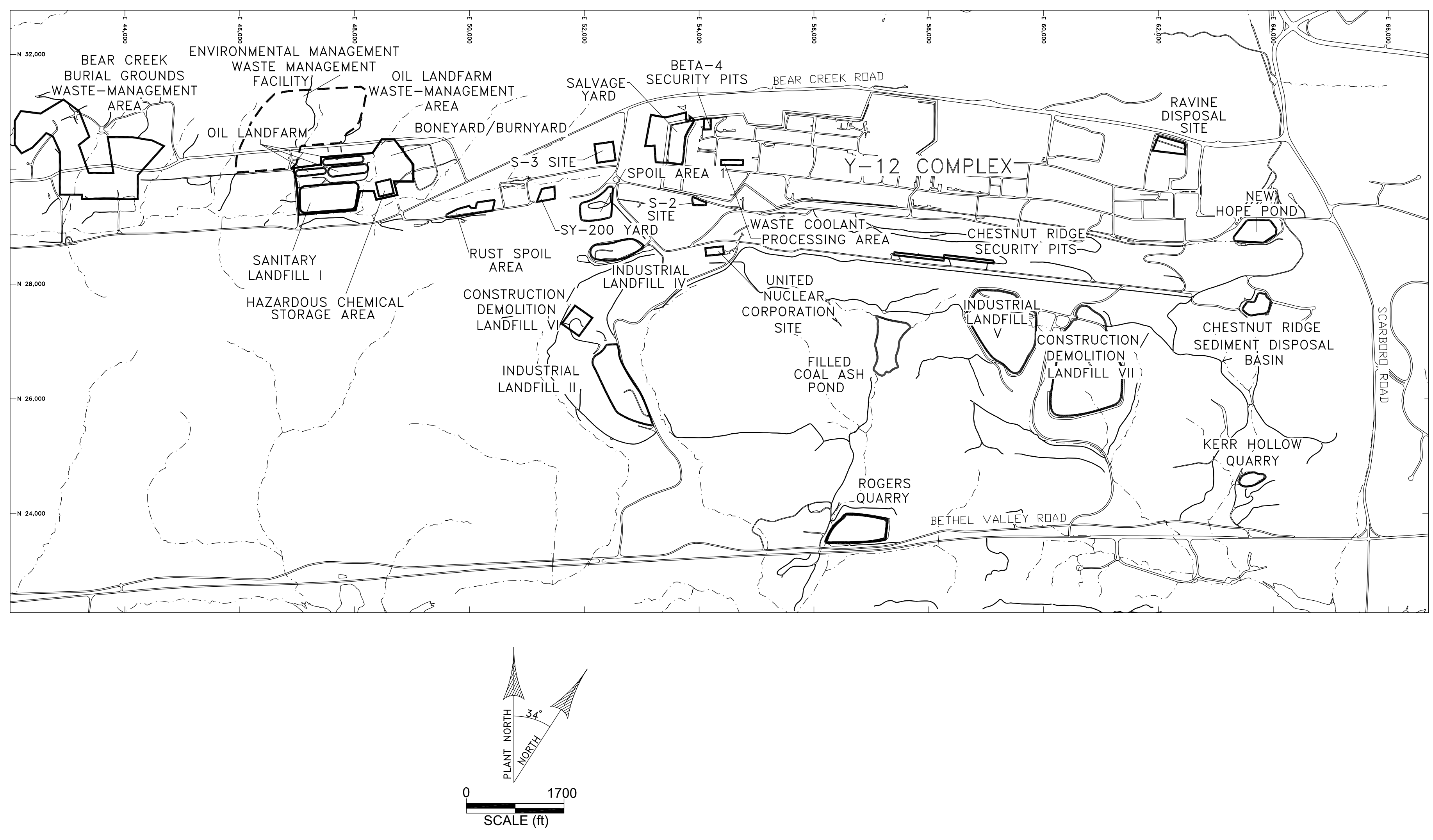


mercury losses and unaccounted mercury inventories. This investigation involved the installation of 43 monitoring wells, aquifer testing in selected wells, collection of soil and groundwater samples, and laboratory analyses of the samples. Results of the investigation were presented in a report issued in 1984 (Rothschild et al. 1984).

Also in 1983, the TDEC issued an operating permit for a non-hazardous solid waste landfill (Industrial Landfill II) located near the crest of Chestnut Ridge south of Y-12 (Figure 3). Groundwater monitoring in accordance with the detection monitoring requirements specified in the permit was performed until the closure of this solid waste disposal facility (SWDF) in 1996.

In December 1983, the TDEC issued a Complaint and Order requiring DOE to immediately cease further groundwater contamination by disposal of solid wastes in the BCBG and to submit a written proposal and schedule (with supporting data and rationale) for remedial action in the Bear Creek watershed area. In response, several intensive investigations of hydrogeological conditions in BCV were subsequently initiated to obtain data needed to support a preliminary evaluation of remedial alternatives. These investigations involved three phases of well installation and subsequent groundwater sampling and analysis. The first two well installation phases were completed in late 1983 and early 1984 (Bechtel National, Inc. 1984a, 1984b, 1984c, and 1984d), and the third phase was completed in late 1984 (Bechtel National, Inc. 1985; Geraghty \& Miller, Inc. 1985a and 1985b).

Based on information obtained from the hydrogeologic investigations performed in 1983 and 1984, additional monitoring wells were installed at several sites in 1985 (Geraghty \& Miller, Inc. 1986). These wells were designed primarily to investigate the deeper portions of the groundwater flow system at these waste disposal sites. Typically, the wells were installed adjacent to other wells to form clusters. An evaluation of the groundwater quality data and an analysis of deep-well recovery behavior were presented in a report issued in 1987 (Geraghty \& Miller, Inc 1987).

Five monitoring wells also were installed in 1985 at several locations in cooperation with a continuing hydrogeologic investigation initiated by the USGS. Additionally, deep core holes were drilled for hydrogeologic characterization purposes at Kerr Hollow Quarry (KHQ) and the CRSDB.

Also in 1985, monitoring wells were installed in compliance with requirements of the Resource Conservation and Recovery Act (RCRA) regulations governing several hazardous waste management sites at Y-12, including the Chestnut Ridge Security Pits (CRSP), New Hope Pond, the CRSDB, and KHQ (Figure 3). Other monitoring wells also were installed for hydrogeologic characterization purposes at several non-hazardous waste management sites, including the Beta-4 Security Pits, the Ravine Disposal Site, Rogers Quarry, and the United Nuclear Corporation Site (UNCS). Groundwater samples were collected from each well and water-levels in the wells were regularly measured. Information on site investigation planning, well placement and construction, site hydrogeology, a preliminary evaluation of the hydrogeologic information, and groundwater-quality data obtained from the wells is provided in three separate reports (Haase et al. 1987a, 1987b, and 1987c).

A hydrogeologic investigation at Y-12 was performed during 1985 by researchers with the ORNL. During this investigation, core holes were drilled at four locations in the vicinity of Y-12 to characterize subsurface geological and hydrological conditions to depths of $1200 \mathrm{ft}$ below ground surface (King and Haase 1987 and 1989). 


\section{6 - 1989}

Continued groundwater monitoring investigations were performed between 1986 and 1989 in support of RCRA interim status assessment monitoring requirements, and these investigations primarily involved the installation and sampling of additional monitoring wells. During this period, 160 monitoring wells were added to the well network at Y-12, with most of the wells sampled on a quarterly frequency. The analytical data obtained from these wells and an interpretation of the data were presented in a series of site-specific reports submitted annually to the TDEC and the EPA. Also, between 1987 and 1989, ORNL researchers performed additional characterization studies, including an intensive hydrogeologic investigation that involved installation of wells at a site in BCV approximately 5 miles west of Y-12 (Lee and Ketelle 1989).

In November 1988, DOE issued Order 5400.1, which specified the establishment of a groundwater protection management program at each DOE facility. In response, the Y-12 GWPP was formally established to effectively manage the rapidly expanding groundwater sampling and analysis activities, define standardized programmatic elements (e.g., monitoring well designs), and coordinate data management and reporting (King and Haase 1990).

In 1989 the TDEC issued an operating permit for another non-hazardous waste landfill (Industrial Landfill IV) located south of Y-12 on Chestnut Ridge (Figure 3). Groundwater monitoring wells were installed at the site and sampled in accordance with the detection monitoring requirements specified in the permit; the GWPP Organization assumed responsibility for the associated groundwater sampling and analysis activities.

\section{0 - 1996}

In 1990, the GWPP issued a completely revised comprehensive groundwater monitoring plan for Y-12 (hereafter referenced as the Comprehensive Monitoring Plan) that addressed the extensive expansion of regulatory requirements and groundwater monitoring activities performed by the GWPP since the original master plan was issued. The Comprehensive Monitoring Plan presented a groundwater and surface-water quality monitoring strategy based on a technical approach that incorporated the characteristics of the hydrogeologic system at Y-12 and maintained compliance with all applicable state and federal regulatory requirements, DOE Orders, and EPA technical guidance (Geraghty \& Miller, Inc. 1990).

Beginning in September 1990 and continuing until September 1992, the GWPP installed and sampled 68 monitoring wells at Y-12 under two components of the technical framework presented in the Comprehensive Monitoring Plan: the Grid Well Program and the Maynardville Exit Pathway Program. The Grid Well Program established the monitoring well coverage in the East Fork Regime that was needed to assess the overall extent of groundwater contamination within the heavily industrialized areas of Y-12. Also, the Grid Well Program provided wells suitable for DOE Order 5400.1 requirements regarding surveillance of contaminant sources at DOE facilities. The Maynardville Exit Pathway Program, in conjunction with the installation of multiport groundwater sampling equipment in several deep (approximately 600 to 1,400 ft) core holes, provided data needed to help characterize groundwater flow patterns and to define extent of contamination within the Maynardville Limestone, which is the principal pathway for groundwater and surface water transport of contaminants from sources at Y-12. Monitoring wells installed under the Maynardville Exit Pathway Program also serve DOE Order 5400.1 requirements for monitoring at locations where contaminants from DOE facilities are most likely to migrate off-site. 
In conjunction with the installation of monitoring wells at Y-12 during the early 1990s, the GWPP also initiated a comprehensive monitoring well plugging and abandonment (P\&A) program. The objective of the P\&A program was to remove from service many of the obsolete monitoring wells that were installed at Y-12 during the 1970s and early 1980s, along with other wells that had been irreparably damaged. Implementation of the P\&A program enabled the GWPP to develop and refine effective $\mathrm{P} \& \mathrm{~A}$ procedures that ensure the proper removal of all monitoring well components.

Several regulatory agreements signed in the early 1990s substantially impacted the Y-12 GWPP. Effective in January 1992, the Federal Facility Agreement (FFA) negotiated by DOE, EPA, and the TDEC addressed environmental restoration under the Comprehensive Environmental Response, Compensation and Liability Act (CERCLA) on the Oak Ridge Reservation (ORR), which was added to the National Priority List in November 1989. The FFA established CERCLA as the regulatory program governing clean-up of the ORR, including corrective action for the RCRA-regulated hazardous waste treatment, storage, and disposal (TSD) units at Y-12. As such, the DOE appealed the applicability of RCRA post-closure care, corrective action, and groundwater monitoring requirements to any TSD unit that was also classified as a CERCLA operable unit (OU) under the FFA. Under this agreement, RCRA would be applied as an applicable or relevant and appropriate requirement to the extent that post-closure maintenance and care of the former TSD facilities will be conducted in compliance with the terms of a RCRA post-closure permit (PCP).

In April 1993, the DOE, TDEC, and the Y-12 M\&O subcontractor (Martin Marietta Energy Systems, Inc.) signed an Agreed Order that resolved the appeal. Under this agreement, RCRA corrective action at the former TSD facilities is deferred to the CERCLA remedial investigation (RI)/feasability study (FS) process, with post-closure care and maintenance activities at these sites (including groundwater monitoring) performed under the terms and conditions of the applicable RCRA PCP issued by the TDEC.

Subsequent to the 1993 Agreed Order, the TDEC issued three RCRA PCPs, one in September 1995 that defined the post-closure care and monitoring requirements for three closed TSD units (S-3 Site, Oil Landfarm, and Bear Creek Burial Grounds/Walk-In Pits) located in the Bear Creek Regime; a second in June 1996 that addressed post-closure care and monitoring requirements for three closed TSD units (CRSP, CRSDB, and KHQ) located in the Chestnut Ridge Regime; and a third in August 1996 that defined the post-closure care requirements for a closed TSD unit (New Hope Pond) and the post-closure monitoring requirements for a primary contaminant source area (Eastern S-3 Site Plume) located in the East Fork Regime. The GWPP assumed responsibility for implementation of the RCRA groundwater monitoring specified by each PCP, including sample collection and analysis, data management, and reporting.

In 1994, the FFA strategy for RI/FS implementation on the ORR began to evolve. The FFA originally defined two types of CERCLA OUs for which an RI/FS would be performed: (1) source control OUs comprised of individual or groups of waste management sites, and (2) integrator OUs that encompass groundwater and surface water, independent of the source control OUs that may contribute to the contamination of these media (DOE 1994). However, it soon became evident that separation of source control and integrator OUs was not technically feasible and an agreement was subsequently reached among regulatory agencies and the DOE to implement an integrated RI/FS approach. This integrated approach addressed source and integrator OUs concurrently in a 
Characterization Area (CA) defined by watershed boundaries, with specific sites or locations of highest risk or concern in each CA targeted for focused studies.

In 1994, the TDEC issued operating permits for three additional SWDFs on Chestnut Ridge south of Y-12 (Industrial Landfill V, Construction/Demolition Landfill VI, and Construction/ Demolition Landfill VII). Groundwater monitoring wells were installed at each site and subsequently sampled in accordance with the SWDF detection monitoring requirements specified in the respective operating permit (and governing TDEC regulations). The GWPP assumed responsibility for the groundwater sampling, analysis, and reporting activities for each of these sites.

\section{$1996-2000$}

Beginning in the mid-1990s, the overall responsibility for groundwater and surface water monitoring activities at Y-12 began to fragment. In 1996, the Integrated Water Quality Program (IWQP) was established to coordinate groundwater monitoring activities performed in support of CERCLA activities on the ORR. Implementation of CERCLA-related groundwater monitoring at Y-12 began in 1997 under the auspices of the IWQP, with the GWPP providing monitoring data and associated technical support as requested. The BCV RI Report was issued in 1997 to formally characterize the nature and extent of contamination, evaluate the fate and transport of contaminants, and assess the risk to human health and the environment under CERCLA (DOE 1997).

In addition to CERCLA monitoring in direct support of the RI/FS process at Y-12, the IWQP also encompassed groundwater monitoring activities performed in compliance with requirements of each CERCLA record of decision (ROD) for DOE facilities on the ORR. Accordingly, in 1997 the IWQP assumed programmatic responsibility for monitoring in compliance with the respective final ROD for the UNCS, KHQ, and the Filled Coal Ash Pond (FCAP), as well as a recently finalized RODs concerning remedial actions in BCV. However, groundwater monitoring is specifically required only by the ROD for the UNCS. Conversely, the ROD for the FCAP does not require groundwater monitoring, but the ROD for KHQ defers CERCLA groundwater monitoring to the RCRA PCP for the site. The ROD for BCV establishes general goals for groundwater monitoring, but the detailed monitoring requirements for the decision document are specified in a subsequent remedial design work plan for the Watershed (DOE 2001). An Engineering Evaluation/Cost Analysis for the East End Volatile Organic Compound Plume and attendant action memoranda also specify groundwater monitoring for a plume intercept action in the East Fork Regime.

In 1997, the GWPP changed the method of groundwater monitoring well sampling to improve cost effectiveness and waste minimization. On October 1, 1997 the primary sampling method was changed from the conventional three well volume purge and sample method (hereafter referred to as the conventional sampling method) to the low-flow minimal drawdown purge and sample method (hereafter referred to as the low-flow sampling method). The conventional sampling method requires the use of portable gas driven piston pumps to remove at least three well volumes of groundwater from the well to ensure that all resident, and potentially stagnant, water was removed and that samples taken from the well were of representative groundwater. This method produced large quantities (approximately 50,000 gallons annually) of waste water requiring containment, transportation, treatment and disposal. Additionally, since these pumps are portable and were used in multiple wells, decontamination and rinsate sampling was required for quality assurance. The low-flow method requires the use of dedicated gas-driven bladder pumps and the containment of minimal quantities of waste water (approximately 1000 gallons annually). The low-flow method 
required less time to perform; containment and treatment requirements were drastically reduced; and no QA (rinsate) sampling was required since dedicated systems were utilized. Furthermore, comparative studies of the two methods indicated that $90 \%$ of the wells monitored show no significant difference in water quality results. The other $10 \%$ were impacted by local geologic conditions (i.e., flowpaths, transmissivity) and proximity to contaminant plumes (BWXT 2002).

In 1998, DOE selected Bechtel Jacobs Company L.L.C. (BJC) as the management and integration contractor responsible for implementation of environmental restoration and waste management activities on the ORR. Beginning in April 1998, BJC began to assume the programmatic responsibility for implementing the RCRA post-closure groundwater monitoring programs specified in the PCPs for the Bear Creek, Chestnut Ridge, and East Fork hydrogeologic regimes. The GWPP continued to coordinate RCRA PCP sampling, analysis, and reporting through December 1998 for consistency in data quality. These groundwater monitoring and reporting activities are now performed as an integrated component of the BJC Water Resources Restoration Program (WRRP) which evolved from the IWQP. The Upper East Fork Poplar Creek CA RI Report was issued in August 1998 and in November 1998, BJC also assumed programmatic responsibility for operation and management of the non-hazardous landfills on Chestnut Ridge. However, BJC retained the GWPP to continue the corresponding SWDF detection monitoring programs through December 1999, when a BJC subcontractor assumed responsibility for groundwater monitoring and reporting at each landfill.

In November 2000, DOE selected BWXT as the Y-12 M\&O contractor who subsequently assumed responsibility for all Y-12 operations from the previous M\&O contractor (Lockheed Martin Energy Systems, Inc.[LMES]).

\section{1 - Present}

In December 2002, to comply with federal and state Underground Injection Control (UIC) requirements of the SDWA, a Class V Injection Well inventory for Y-12 was submitted to the EPA (Region IV) and a UIC permit application was submitted to the TDEC. In preparing the inventory, many of the steam condensate discharge dry wells located throughout Y-12 were determined to meet the definition of a Class V injection well, and a UIC compliance effort (see Section 2.3.2) was initiated by the GWPP to meet applicable UIC requirements and ensure protection of groundwater at Y-12. Also, administrative controls, such as engineering standards and inclusion in the National Environmental Policy Act review process, were enacted to ensure that the addition, closure, or modification of any Class V injection well at Y-12 is performed in compliance with these state and federal regulations.

In January 2003, DOE replaced Order 5400.1 with Order 450.1. This transition from a command and control-based approach to environmental protection to an environmental management system (EMS) was federally mandated through Executive Order 13148. The GWPP reviewed the new DOE Order and determined that the requirements for an integrated approach to monitoring and protection of groundwater resources are consistent with current practices of the respective groundwater programs on the ORR. Thus, no changes were proposed or implemented.

The TDEC issued new RCRA PCPs for the East Fork Regime and the Bear Creek Regime in September 2003 and December 2003, respectively. The previous PCP for each regime expired in 
September 2001, but remained effective pending the permit re-application and renewal process. The new PCP for each regime specifies different requirements for RCRA post-closure corrective action groundwater monitoring than expired PCP for each regime. The new PCP for each regime retained the same point of compliance (POC) wells specified for each site and the same plume boundary/plume delineation for each regime, but removed the upgradient/background well from each RCRA monitoring network and modified the site-specific suites of analytical parameters applicable to the POC wells and plume boundary/plume delineation wells.

\subsection{ONGOING GROUNDWATER MONITORING ACTIVITIES AT Y-12}

Groundwater monitoring activities at Y-12 are no longer performed under one comprehensive program. Nevertheless, the individual programs, which have differing technical objectives and requirements, coordinate sampling and analysis activities to ensure efficient use of monitoring resources. Through cooperative and integrated implementation, the programs achieve mutual programmatic goals, ensure data equivalency between programs, and eliminate redundancies. Ongoing groundwater monitoring activities at Y-12 include: (1) surveillance monitoring by the GWPP in direct support of the groundwater monitoring requirements and guidance specified under DOE Order 450.1; (2) RCRA post closure detection monitoring and RCRA post closure corrective action monitoring (collectively referenced as RCRA monitoring) by the WRRP, as specified in the applicable PCPs issued by the TDEC; (3) monitoring in support of CERCLA-related activities at Y-12 by the WRRP; (4) SWDF detection monitoring by the BJC Waste Management Organization in accordance with site-specific landfill operating permits issued by the TDEC; and (5) groundwater elevation monitoring. A short description of each monitoring program is provided in the following sections.

\subsubsection{DOE Order 450.1 Monitoring}

Key requirements of DOE Order 450.1 are the monitoring of groundwater that is or could potentially be affected by facility operations and to provide a reporting mechanism that effectively document the impacts of facility operations on groundwater in order to:

- determine baseline conditions of groundwater quality and quantity;

- demonstrate compliance with and implementation of all applicable state and federal regulations and DOE orders;

- ensure early detection of groundwater pollution or contamination;

- identify existing and potential groundwater contamination sources and to maintain surveillance of these sources;

- evaluate groundwater quality in areas where contaminants have the potential to migrate off-site; and 
- $\quad$ support decisions concerning land-use practices and the management of groundwater resources.

These DOE Order 450.1 objectives are achieved through implementation of the RCRA, CERCLA, and SWDF groundwater monitoring programs at $\mathrm{Y}-12$ in conjunction with the groundwater and surface water surveillance monitoring activities performed by the Y-12 GWPP. These GWPP monitoring activities are performed in accordance with the monitoring strategy presented in the Environmental Monitoring Plan for the Oak Ridge Reservation (DOE 2003), and are implemented as either site surveillance monitoring (hereafter referenced as Surveillance Monitoring), or exitpathway/perimeter monitoring (hereafter referenced as Exit-Pathway Monitoring).

Under the GWPP, groundwater sampling and analysis activities for Surveillance Monitoring are directed at known or suspected sources of groundwater contamination at Y-12 which are not otherwise addressed under the ongoing RCRA, CERCLA, and SWDF monitoring programs. The network of monitoring wells that are specifically sampled for DOE Surveillance Monitoring purposes changes from year to year, depending on funding levels and sampling priority (see Section 5.5), and varies between hydrogeologic regimes, depending on the extent of monitoring coverage provided by the RCRA, CERCLA, and SWDF monitoring programs. Additionally, Surveillance Monitoring also encompasses groundwater sampling and analysis activities associated with special hydrogeologic studies implemented by the GWPP. All sampling and analysis activities are performed in accordance with standardized GWPP monitoring protocols. Monitoring results obtained each calendar year (CY) are presented in the corresponding annual Groundwater Monitoring Report (GWMR) issued by the GWPP (see Section 3.1.6).

Exit-Pathway Monitoring at Y-12 involves collection of groundwater samples from generally fixed networks of perimeter monitoring stations (wells and surface water sampling points) in the Bear Creek and East Fork hydrogeologic regimes, and selected springs and sampling points in surface drainage features that traverse the Chestnut Ridge Regime. The designated perimeter monitoring wells in the Bear Creek Regime are located southwest of the BCBG along a strike-normal transect across the Maynardville Limestone (Figure 2), which is the primary pathway for Y-12 groundwater contaminants to migrate beyond the ORR property boundary. Several perimeter monitoring wells at the eastern end of Y-12 in the East Fork Regime also are located along a strike-normal transect across the Maynardville Limestone, with additional perimeter wells located northeast of Y-12 where Upper East Fork Poplar Creek passes through a gap in Pine Ridge (Figure 2). Instead of perimeter monitoring wells in the Chestnut Ridge Regime, a series of springs that discharge into local surface drainage features on the southern flank of Chestnut Ridge are sampled for the purposes of ExitPathway Monitoring. All sampling and analysis activities associated with Exit-Pathway Monitoring in each hydrogeologic regime are performed in accordance with standardized GWPP monitoring protocols and are included in the annual GWMR issued by the GWPP.

\subsubsection{UIC Compliance}

The Y-12 UIC Compliance effort was initiated in response to changes in state and federal regulations governing underground injection. Presently, the EPA (Region IV) has primacy of UIC compliance through the SDWA and the associated requirements specified in Title 40 Code of Federal Regulations (40 CFR) Parts 144-147. The EPA works with state and local governments to 
oversee underground injection of waste in order to prevent contamination of drinking water resources. The State of Tennessee is in the process of gaining primacy of the UIC program, and has implemented regulatory standards dictating a response from those agencies and industries which operate injection wells as defined under TDEC Rule 1200-4-6.

The GWPP assumed responsibility for implementation of the Y-12 UIC Compliance effort. The GWPP worked with Y-12 Engineering and Maintenance organizations to inventory the external (outside of buildings) steam piping system and a map was created to locate any type of Class V injection well. The inventory efforts identified two types of Class V injection wells: steam condensate dry wells (also referred to as infiltration cells or french drains) and septic systems serving more than 20 people. In December 2002 the UIC inventory for Y-12 was submitted to EPA and a permit application was filed with TDEC to comply with federal and state requirements. Ongoing activities include: (1) maintaining the UIC inventory as required, submitting required updates and changes to EPA and TDEC, and (2) implementing engineering standards and administrative controls to ensure compliance with UIC requirements for new construction, facility demolition, and maintenance activities at Y-12.

\subsubsection{RCRA Compliance Monitoring}

As noted in Section 2.2, RCRA post-closure groundwater monitoring at former TSDs associated with Y-12 is required under three separate PCPs issued by the TDEC, one for the Bear Creek Regime (TDEC permit number TNHW-116), one for the Chestnut Ridge Regime (TDEC permit number TNHW-088), and one for the East Fork Regime (TDEC permit number TNHW-113). All groundwater sampling and analysis activities in direct support of ongoing RCRA-related groundwater monitoring are performed by the WRRP. An overview of the groundwater monitoring requirements specified in each PCP is provided below.

\section{Bear Creek Regime}

The PCP for the Bear Creek Regime defines the requirements for RCRA post-closure corrective action groundwater monitoring at the S-3 Site (formerly the S-3 Ponds), the Oil Landfarm, and the BCBG (Figure 3). Monitoring at these sites generally involves semiannual collection of groundwater samples from a RCRA monitoring well network that consists of at least one POC well designated for each site, and a common series of downgradient plume boundary wells. Samples collected from each well are analyzed for a site-specific suite of RCRA groundwater target constituents. Analytical results for these constituents (along with groundwater elevations determined from pre-sampling measurements of the depth-to-water in each well) are reported to the TDEC semiannually. An evaluation of the monitoring data obtained for each POC well and plume boundary well, along with a review of groundwater flow directions and a calculated rate of groundwater flow in the uppermost aquifer, is included in an annual RCRA Monitoring Report submitted to the TDEC by March 1 of each CY. Evaluation of the monitoring results is based on quantitative trend analysis of data for selected RCRA target constituents that are primary components of plume of contaminants in the groundwater at each site.

\section{East Fork Regime}

The PCP for the East Fork Regime defines the RCRA post-closure corrective action groundwater monitoring requirements for the Eastern S-3 Ponds Plume, which is a subsurface reservoir of 
contamination that was emplaced during operation of the former S-3 Ponds. As in the Bear Creek Regime, this monitoring program involves semiannual collection of groundwater samples from a RCRA monitoring well network consisting of at least one of the POC wells designated for the Eastern S-3 Ponds Plume, and a series of downgradient plume delineation wells. Samples collected from each POC well are analyzed for the specified suite of RCRA groundwater target compounds and samples from the plume boundary wells are analyzed for technetium-99 (Tc-99), which is the "signature" contaminant within the Eastern S-3 Ponds Plume. Monitoring results (along with the pre-sampling groundwater elevation in each well) are reported to the TDEC semiannually. An evaluation of the monitoring data, including a review of the groundwater flow patterns and a calculated rate of groundwater flow in the uppermost aquifer, is included in the annual RCRA Monitoring Report submitted to the TDEC by March 1 of each CY. As specified in the PCP, this evaluation involves quantitative trend analysis of the monitoring results for the POC well(s) and review of the Tc-99 results reported for the plume boundary wells.

\section{Chestnut Ridge Regime}

The PCP for the Chestnut Ridge Regime defines the requirements for RCRA post-closure corrective action monitoring at the CRSP (Figure 3 ). This monitoring program requires semiannual collection of groundwater samples from the designated RCRA monitoring well network for the CRSP, which includes a background well hydraulically upgradient of the site, at least one of the designated POC wells immediately downgradient of the site, and several plume boundary wells located downgradient of the dissolved plume(s) of volatile organic compounds originating from the site. The groundwater samples from each RCRA well are analyzed for a suite of groundwater target compounds specified in the PCP and the analytical results (along with the pre-sampling groundwater elevation in each well) are reported to the TDEC semiannually. An evaluation of the monitoring data, including a review of the groundwater flow patterns and calculated rate of groundwater flow in the uppermost aquifer, is included in the annual RCRA Monitoring Report submitted to the TDEC by March 1 of each CY.

The PCP for the Chestnut Ridge Regime also defines the requirements for RCRA post-closure detection monitoring at the CRSDB and KHQ (Figure 3). Both monitoring programs require semiannual collection of groundwater samples from at least one upgradient/background well and three POC wells at each site. Groundwater samples from the wells at each site are analyzed for the respective list of RCRA groundwater target compounds specified in the PCP. The sampling results are statistically evaluated to determine if the concentration of any groundwater target compound in any POC well at either site exhibits a statistically significant increase over the corresponding concentration in the respective upgradient/background well(s). Monitoring results obtained at each site are reported to the TDEC semiannually. An annual RCRA Monitoring Report containing detailed statistical evaluation data along with an evaluation of the groundwater flow direction and rate in the uppermost aquifer at each site also is submitted to the TDEC before March 1 of each CY.

\subsubsection{CERCLA Compliance Monitoring}

Groundwater monitoring in support of on-going CERCLA activities at Y-12 fall under two general programs: CERCLA baseline monitoring and CERCLA remedial effectiveness monitoring. CERCLA baseline monitoring generally involves semiannual sampling of a variable network of monitoring wells, springs, and surface water stations located in each of the three hydrogeologic 
regimes at Y-12. These monitoring results serve as the basis for comparison with the results of CERCLA remedial effectiveness monitoring, as defined under the applicable final ROD or decision documents pending final approval and implementation. At this time, a final ROD has been issued for three individual waste management sites associated with Y-12 (the UNCS, KHQ, and the FCAP); a final ROD addressing CERCLA remedial action in BCV also was recently approved. As noted previously, however, only the final ROD for the UNCS requires groundwater monitoring. Ongoing CERCLA remedial effectiveness monitoring at the UNCS involves semiannual collection of groundwater samples from six monitoring wells at the site, and laboratory analysis of the samples for the parameters and constituents specified in the ROD. All groundwater sampling and analysis activities in direct support of ongoing CERCLA-related groundwater monitoring are performed by the WRRP.

Groundwater monitoring under CERCLA is also performed at the Environmental Management Waste Management Facility (EMWMF) in accordance with the EMWMF Environmental Monitoring Plan (EMP) issued by the BJC-subcontractor responsible for operation and management of the site (Duratek Federal Services 2003). The EMWMF is a state-of-the art landfill located in BCV west of Y-12 that is used for the disposal of hazardous and mixed waste generated from CERCLA remedial actions on the ORR. Prior to the disposal of any waste at the site, which began in May 2002, a network of new and existing groundwater monitoring wells along with selected surface water stations were sampled quarterly for one year to establish baseline groundwater and surface water quality at the site. Currently, the network of wells and surface water stations specified in the EMWMF EMP are sampled at least quarterly, with some of the surface water stations sampled monthly. The groundwater and surface water samples are analyzed for a suite of baseline site-related contaminants that is updated periodically with constituents that are components of the wastes disposed at the site or are detected in the leachate collected from the site.

\subsubsection{SWDF Compliance Monitoring}

As noted in Section 2.2, operating permits issued by the TDEC and the governing non-hazardous solid waste management regulations establish the requirements for ongoing groundwater monitoring at the following active SWDFs in the Chestnut Ridge Regime: Industrial Landfill IV, Industrial Landfill V, Construction/Demolition Landfill VI, and Construction/Demolition Landfill VII. Industrial Landfill II was closed in 1996 and Post-Closure detection monitoring is also ongoing. The SWDF detection monitoring program at each landfill involves sampling a minimum of three

monitoring wells; one background well hydraulically upgradient of the site and at least two wells hydraulically downgradient of the site. Groundwater samples collected from the wells at each site are analyzed for the suite of GWPS constituents specified in the respective operating permit for each facility. Analytical results (including pre-sampling groundwater elevations in each well) obtained at each landfill are submitted to the TDEC in accordance with the reporting schedule specified in the respective operating permit. As noted in Section 2.2, ongoing SWDF detection monitoring activities are performed, documented, and reported by the BJC waste management organization. 


\subsubsection{Groundwater Elevation Monitoring}

As noted in the preceding descriptions of the ongoing groundwater monitoring activities at Y-12, the depth to the static water level is measured whenever a monitoring well is sampled. Aside from meeting applicable regulatory requirements, however, the groundwater surface elevations determined from these pre-sampling water level measurements are of limited use because the depthto-water in some wells may be influenced when nearby wells are sampled. Also, it typically takes several months to complete sampling of the specified network of monitoring wells in each hydrogeologic regime; therefore, the pre-sampling water levels are not sufficiently contemporaneous. Moreover, the network of wells used for ongoing groundwater quality monitoring purposes does not provide the spatial coverage needed to determine flow patterns throughout the Y-12 area.

In order to obtain more contemporaneous water-level data, and to ensure that representative groundwater surface elevations are determined, water-level monitoring is performed annually, independent of groundwater sampling activities in the Bear Creek, East Fork, and Chestnut Ridge hydrogeologic regimes. The annual water-level monitoring uses a fixed network of hydrologic monitoring wells designated in the Y-12 Monitoring Optimization Plan (MOP) (see Section 5.5), with the depth-to-water in each designated well measured over a short period (approximately one week) during alternating seasonally high and seasonally low groundwater flow conditions. Groundwater elevations determined from the depth-to-water measurements, which are obtained in cooperation with other organizations involved with groundwater monitoring at Y-12 (see Section 3.3), are suitable for evaluating groundwater flow patterns throughout each hydrogeologic regime and for determining representative horizontal and vertical hydraulic gradients. Depth-towater measurements and corresponding groundwater elevations in each well are presented in several reports, including the annual RCRA post-closure groundwater monitoring reports issued by BJC for each hydrogeologic regime and the annual GWMR issued by the GWPP. 


\subsection{Y-12 GWPP MANAGEMENT STRATEGY}

The primary objective of the Y-12 GWPP is to ensure effective groundwater quality monitoring at Y-12 consistent with all applicable state and federal regulations, DOE orders, and BWXT corporate policy to protect groundwater resources from operational impacts. The GWPP management strategy to achieve this goal encompasses four key elements: (1) standardized groundwater monitoring protocols; (2) proactive stewardship of the extensive monitoring well network at Y-12; (3) productive interaction and cooperation with other organizations responsible for groundwater monitoring at Y-12; and (4) continued assessment of and innovation to the technical approach for groundwater monitoring at $\mathrm{Y}-12$.

\subsection{MONITORING PROTOCOLS}

All groundwater monitoring activities performed by the GWPP are based on the following protocols developed from lessons learned during over 20 years of monitoring experience at Y-12: (1) detailed annual sampling and analysis planning, (2) a semiannual sampling frequency (unless otherwise required), (3) established monitoring-well design and construction standards, (4) technically appropriate and regulatory-approved sampling procedures and analytical methods, (5) predesignated suites of analytical parameters; (6) a specified process for identifying analytical results which do not meet data quality objectives (DQOs); and (7) timely and comprehensive reporting.

\subsubsection{Annual Sampling and Analysis Planning}

All monitoring wells, springs, or surface-water stations to be sampled by the GWPP during each CY are identified in a single annual Sampling and Analysis Plan (SAP) (see Section 5.4). The selection of sampling locations included in the SAP depends on the applicable sampling prioritization criteria described in the Y-12 MOP (see Section 5.5). The SAP specifies the sequence in which each well, spring, and surface water station is sampled so that instances of cross-contamination are avoided. Additionally, the SAP specifies the sampling frequency and analytical parameters for each sampling location, along with the corresponding quality assurance (QA)/quality control (QC) sampling requirements. Any changes to the planned sampling and analysis activities that may occur during each year, such as the addition or removal of sampling locations or changes to the suite of laboratory analyses for each sampling location, are documented in addenda to the SAP. This approach has proven very effective for tracking the ongoing status and cumulative costs of groundwater sampling and analysis activities performed by the GWPP.

\subsubsection{Semiannual Sampling Frequency}

Unless otherwise warranted for the purposes of the GWPP, the annual SAP designates a semiannual sampling frequency for each planned sampling location (monitoring well, spring, or surface water station) in each hydrogeologic regime at Y-12. The semiannual sampling events are scheduled to coincide with seasonally wet and seasonally dry flow conditions. An alternative sampling frequency also may be specified for selected sampling locations. For example, new monitoring wells that are 
installed by the GWPP are sampled for at least four consecutive quarters in order to establish baseline water quality conditions.

\subsubsection{Monitoring Well Designs}

Since 1986, the GWPP has employed two standardized monitoring well designs: completion with an open-hole monitored interval and completion with a manufactured well screen. Both standardized well designs meet applicable installation and construction standards defined in the RCRA technical enforcement guidance document issued by the EPA (EPA 1992). Use of standardized well designs and construction materials minimizes the potential effects on watersample quality resulting from varying well completion and construction methods.

\subsubsection{Sampling Procedures and Analytical Methods}

Standard operating procedures are used by the GWPP for the sampling of groundwater and surface water. These procedures comply with applicable regulatory requirements and DOE Orders; are based on technical standards contained in EPA technical guidance documents; and are functionally equivalent to the sampling procedures used at Y-12 by other organizations. For each sampling location, the annual SAP for the GWPP designates applicable groups of analytical parameters (administrative parameter groups) consisting of standardized suites of laboratory analyses, including miscellaneous parameters (e.g., total dissolved solids), inorganic constituents (trace metals and major ions), volatile organic compounds (VOCs), and radiological analytes. All field measurements and laboratory analyses are performed in accordance with TDEC-, EPA-, and DOE-approved methods. The use of approved, standardized sampling procedures greatly reduces the collection of monitoring results that reflect bias from widely divergent monitoring protocols and helps the GWPP to maintain long-term data consistency and to achieve functional equivalency with the results of other groundwater monitoring programs at Y-12.

\subsubsection{Data Quality Objective Screening}

The GWPP employs a standardized data-screening process for identifying groundwater and surface water quality monitoring results that do not meet the applicable DQOs defined in the GWPP Data Management Plan (see Section 5.7). Specific DQO criteria apply to the analytical results for major ions, trace metals, VOCs, radiological analytes (gross alpha, gross beta, and radionuclides), and miscellaneous laboratory analytes (e.g., total dissolved solids). Analytical results that do not meet the specified DQO criteria are appropriately qualified. Developed and refined over more than 15 years of groundwater monitoring at Y-12, the GWPP data-screening process, much of which has been adopted by WRRP, has proven a consistent, objective, and effective means for identifying sampling or analytical artifacts, such as false positive results for VOCs, and other spurious monitoring results. 


\subsubsection{Comprehensive Data Reporting}

Between 1990 and 2003, the GWPP employed a two-part approach for annual reporting of groundwater monitoring data obtained at Y-12. Each CY, all the groundwater monitoring data obtained at Y-12 during the preceding CY were compiled in a GWMR. Accordingly, the annual GWMR combined the monitoring results (field measurements and laboratory analyses) obtained by the GWPP and the monitoring data obtained by other organizations, such as the WRRP. The annual GWMR was accompanied by a separate Groundwater Data Evaluation Report (GWDER), which presented a detailed evaluation of the monitoring data with respect to the requirements of DOE Orders 5400.1 and 450.1 (see Section 2.3.1). Additionally, each annual GWDER served as a forum to present results of supplemental hydrogeologic studies in each regime (see Section 3.4) and to describe proposed modifications to the monitoring activities performed by the GWPP. A separate GWDER for each hydrogeologic regime was issued until CY 2000, when the separate reports were combined.

Beginning in 2003, the GWPP modified the approach for reporting and documenting Y-12 monitoring data in order to demonstrate and maintain compliance with applicable requirements of DOE Order 450.1. The annual GWMR was retained as the single-source reference for the Y-12 monitoring data obtained each CY (see Section 4.8.1.1), but the annual GWDER was replaced by the Y-12 GWPP Monitoring Data Evaluation Compendium (MDEC) (see Section 4.8.1.2). The MDEC serves as the GWPP reference document, updated annually, that provides a comprehensive overview and evaluation of the monitoring data for each sampling location that is granted "active" status in accordance with the Y-12 MOP (see Section 5.5).

The GWPP is committed to reporting to BWXT Management and to DOE any unusual or abnormal groundwater monitoring data as soon as such results become available. In this way, operational impacts to groundwater can be evaluated and an appropriate course of action can be decided upon in a timely manner (see Section 4.8.2).

\subsection{MONITORING SYSTEM STEWARDSHIP}

In the late 1980s the GWPP assumed responsibility for the overall care and maintenance of the many groundwater monitoring wells at Y-12. Stewardship of this extensive monitoring well network, which includes several hundred wells located throughout the Bear Creek, East Fork, and Chestnut Ridge regimes (along with several wells located outside of the ORR), has involved: (1) a program of regular inspection and maintenance, (2) use of standardized P\&A procedures proven to effectively remove or close obsolete or irreparably damaged monitoring wells, and (3) maintaining and updating the database of subsurface geologic data and monitoring well construction details.

All the monitoring wells used for groundwater monitoring at $\mathrm{Y}-12$ except those used for ongoing RCRA, CERCLA, and SWDF monitoring programs are inspected annually by the GWPP; the WRRP currently retains programmatic responsibility for the inspection (and maintenance) of all RCRA and CERCLA monitoring wells and the BJC waste management organization retains responsibility for inspection and maintenance of the SWDF monitoring wells. Additionally, inactive monitoring wells (i.e., wells that are not used for ongoing groundwater monitoring programs) are inspected by the GWPP once every three years. These routine inspections, which focus on the 
applicable above-ground components of each well (including the protective surface casing, well casing, locking well cap, concrete well pads, and vehicle guard posts), and related requests for maintenance work are performed and documented in accordance with GWPP procedures (see Section 5.9). Annually, the GWPP issues a Well Inspection and Maintenance Report (see Section 4.11).

Effective stewardship of the monitoring well network at Y-12 also includes the P\&A of wells that become irreparably damaged or must otherwise be removed or closed to accommodate ongoing operations at Y-12. The removal or closure of monitoring wells is completed in accordance with proven technical procedures that incorporate the lessons-learned during the P\&A of numerous obsolete monitoring wells in the 1990s. Note that the WRRP assumed responsibility for the proper P\&A of any RCRA and SWDF monitoring wells at Y-12 (if needed), and any wells which may interfere or obstruct CERCLA activities.

Drilling records and construction details for the network of monitoring wells at Y-12 include critical information essential to the analysis of groundwater flow characteristics in each hydrogeologic regime, the interpretation of groundwater monitoring results for each well, and evaluation of the suitability of each well for the purposes of ongoing groundwater monitoring programs and supplemental hydrogeologic studies. Beginning in the late 1980s, the GWPP has served as the custodian of these drilling records and well construction data, and has compiled the information in updated versions of a document entitled Updated Subsurface Data Base for Bear Creak Valley, Chestnut Ridge, and Parts of Bethel Valley on the U.S. Department of Energy Oak Ridge Reservation; the most recent version of which was issued by the GWPP in February 2003 (BWXT 2003a).

\subsection{MONITORING ORGANIZATION INTERACTION}

Productive interaction with other organizations responsible for groundwater monitoring at $\mathrm{Y}-12$ is crucial to the overall effectiveness of the GWPP, avoids duplication of monitoring efforts, and effectively directs available resources toward mutual programmatic objectives. Cooperative interaction between the GWPP and other organizations primarily involves coordinating monitoring activities, sharing monitoring data, and providing technical support. For example, the GWPP and WRRP alternately assume responsibility for performing the annual groundwater elevation monitoring at Y-12 (see Section 2.3.6). Similarly, the groundwater and surface water quality data obtained by the GWPP for the purposes of DOE Order 450.1 are shared with WRRP because these results are also suitable to CERCLA baseline monitoring.

\subsection{MONITORING INNOVATION AND IMPROVEMENT}

The GWPP is committed to the continued innovation and improvement of the groundwater monitoring procedures and protocols used at Y-12. This goal is achieved through: (1) efficient use of available monitoring resources; (2) thorough evaluation of the groundwater monitoring data obtained each year and reassessment of data interpretations in light of new monitoring results or findings of hydrogeologic studies; and (3) proactive implementation of programmatic changes in response to monitoring results and evolving monitoring priorities. 


\subsection{Y-12 GWPP ORGANIZATION, ROLES, AND RESPONSIBILITIES}

The GWPP is a multi-element, multi-disciplinary, matrix organization staffed by personnel from Water Compliance Section of the Environmental Compliance Department (ECD) within the Y-12 Environment, Safety, and Health (ES\&H) Division; the line and matrix organization of the GWPP is illustrated on Figures 4 and 5, respectively. The GWPP is responsible for the following:

- Implementing the DOE Order 450.1 Surveillance and Exit Pathway groundwater monitoring program.

- Ensuring that all GWPP activities are performed safely through the implementation of the Y-12 Integrated Safety Management System (ISMS).

- Directing laboratory services in support of monitoring efforts.

- Management of groundwater data and information.

- $\quad$ Reporting as required by DOE orders.

- Providing data, documentation, and analyses to end users and data repositories.

- Maintaining a formal records management system to capture sample chains of custody, analytical packages, data verification/validation documentation, and other required records and technical information.

- Stewardship of the Y-12 groundwater monitoring well network.

- Serving as a technical and service resource to customer organizations.

\subsection{PROGRAM MANAGEMENT}

Management responsibilities for implementation of the GWPP at Y-12 are divided between the GWPP Manager, the GWPP Technical Coordinator, and the GWPP Sampling and Analysis Coordinator.

\subsubsection{GWPP Manager}

The GWPP Manager serves as the primary Y-12 groundwater point of contact for the GWPP matrix organizations (Figure 5), other DOE contractors, regulatory agencies (through Y-12 Management and DOE), and other Y-12 programs as related to National Nuclear Security Administration funded activities. The GWPP Manager is responsible for maintaining the quality of the GWPP and is ultimately responsible for the success of the program as a whole and each of the individual elements. Primary responsibilities of the GWPP Manager include: 


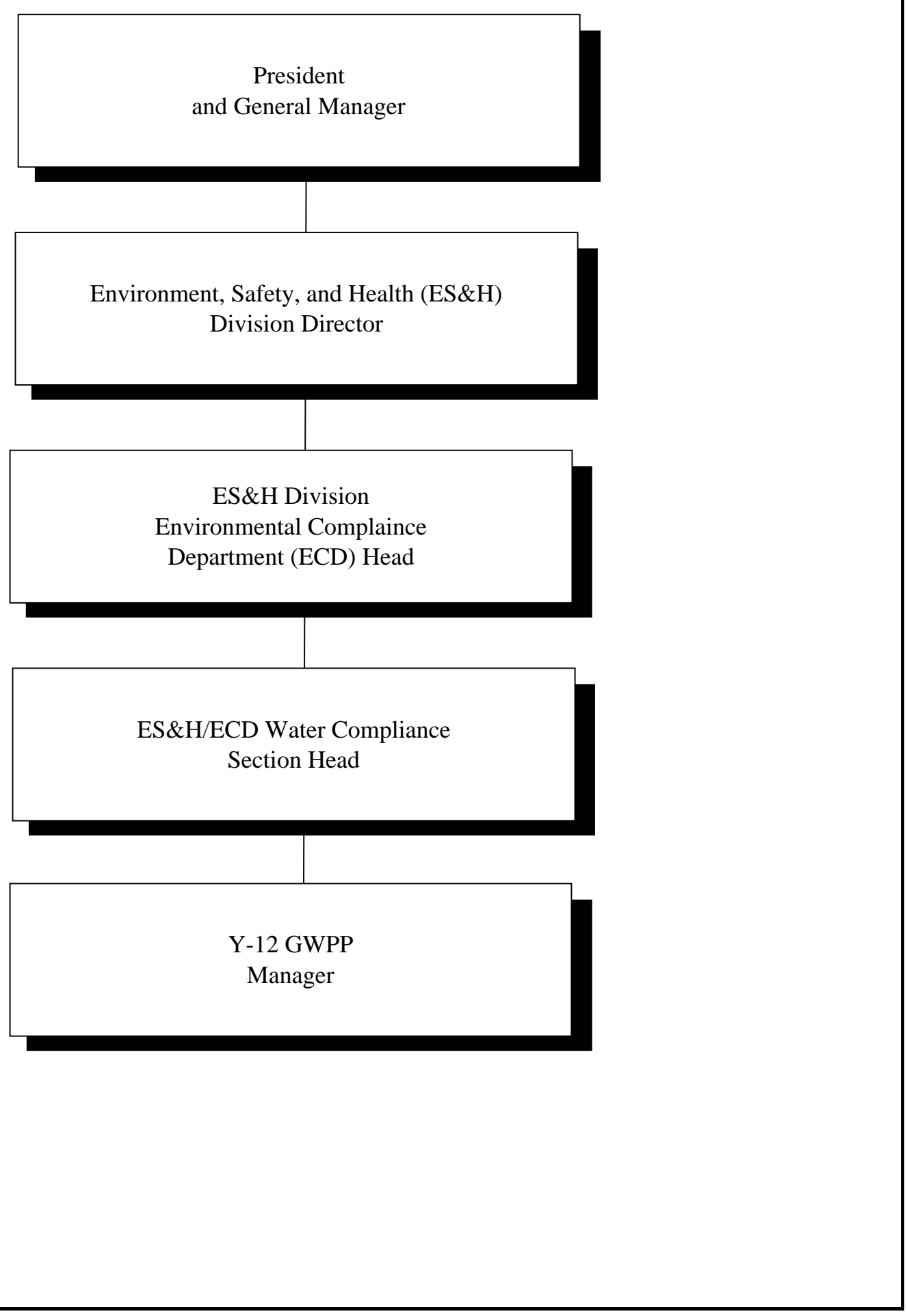

Fig. 4. Line organization of the Y-12 GWPP 


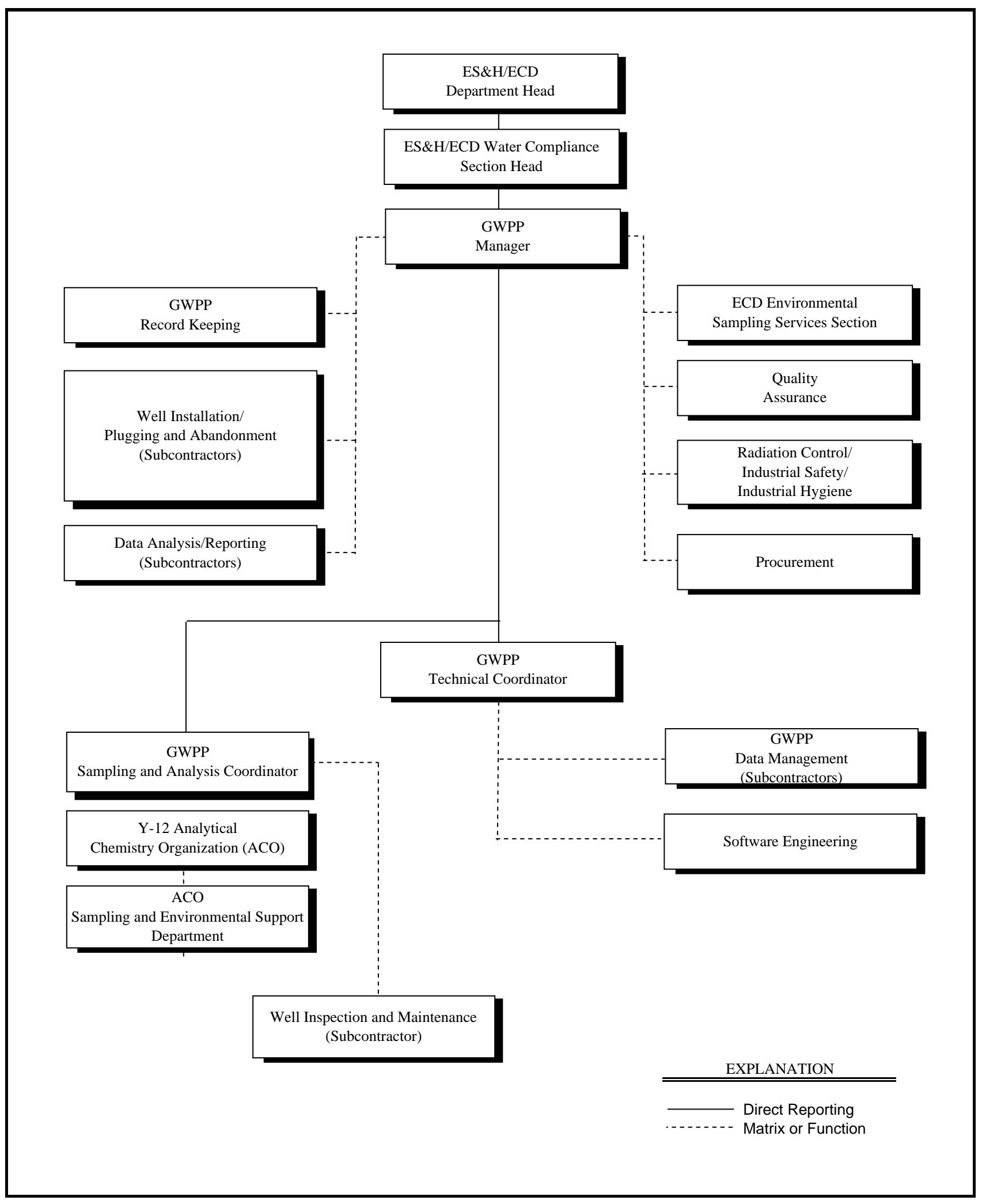

Fig. 5. Matrix organization of the Y-12 GWPP 
- Meeting all groundwater requirements of DOE Order 450.1.

- Implementing the GWPP Management Plan and associated element plans.

- Implementing the sampling and analysis activities associated with DOE Order 450.1.

- Serving as a single point of contact for technical resources to DOE and customer organizations.

- Meeting all classification and security requirements of groundwater data.

- Defining and implementing well drilling, installation, $\mathrm{P} \& \mathrm{~A}$, and inspection/maintenance requirements.

- Interfacing with other Y-12 and ORR organizations, as required.

- Ensuring that all activities performed by the GWPP, its affiliate organizations, and subcontractors meet all requirements of the ISMS at Y-12.

- Eliminate duplication of effort and monitoring facilities by exploiting commonalities in monitoring requirements among separate groundwater programs at Y-12.

\subsubsection{GWPP Sampling and Analysis Coordinator}

The GWPP Sampling and Analysis Coordinator also reports to the GWPP Manager and has primary responsibility for the following:

- Implementation and administration of the annual SAP for the GWPP.

- Development and maintain sampling schedules, bottle lists, and purge water containment requirements on a quarterly basis and as required by additions or deletions to the monitoring network.

- Primary point of contact for tracking and coordinating sampling activities for the sampling personnel.

- Primary point of contact for the characterization and coordination of purge water containment, handling, and disposal activities with the appropriate waste management organizations and subcontractors.

- Primary point of contact with the BWXT Analytical Chemistry Organization (ACO) representative(s) to ensure that analytical methods, analytical parameters, and data reporting schedules are efficiently completed as specified in the SAP.

- Performance of assessments of sampling activities against standard operating procedures to ensure high standards of quality. 
- Development and implementation of ISMS elements for GWPP-related field activities.

- Development and review of standard operating procedures for GWPP field activities.

- Maintain GWPP monitoring activity information in the Groundwater Information Management System (GIMS).

- Act as the GWPP project manager for other specified GWPP activities (e.g, well maintenance, technical evaluations, hydrologic field testing, etc.).

- Provide technical support to the GWPP Manager and customers.

- Define monitoring requirements to be included in the annual SAP for the GWPP, and assist in the preparation and implementation of the SAP and any addenda to the plan.

- Implement corrective actions resulting from field QA deficiencies.

- Maintain monitoring well sampling histories and provide timely notification of any unusual circumstances (e.g., dry well conditions, extraordinarily high or low water levels, vapors or odors noted, discolored water, well damage, missing locks or caps, evidence of tampering, etc.) to the GWPP Manager and ACO Program Manager.

\subsubsection{GWPP Technical Coordinator}

The GWPP Technical Coordinator reports to the GWPP Manager and has primary responsibility to:

- Review hydrogeologic assessments and provide recommendations.

- Coordinate GWPP data management activities (e.g., data verification and validation) with subcontract personnel.

- Update and maintain information (e.g., geographical, well component/construction, maintenance, hydrologic, and water quality) in the GIMS.

- Interface with and direct Software Engineering personnel to maintain and improve the systems and computer tools that comprise the GIMS.

- Coordinate the transfer of GWPP water quality data to the Oak Ridge Environmental Information System (OREIS) in a timely manner.

- Implement the UIC Compliance effort, coordinating with EPA and TDEC, DOE, and other contractors to meet applicable UIC requirements.

- Act as the GWPP project manager for other specified GWPP activities (e.g, drilling operations, technical evaluation, hydrologic field testing, statistical analyses, etc.).

- Provide technical support. 


\subsection{HEALTH AND SAFETY}

Health and safety is implemented for all GWPP field activities through the Y-12 ISMS. Health and safety is the responsibility of the GWPP Program Manager and Coordinators with support from other appropriate organizations such as the Industrial Hygiene and Industrial Safety Departments, and the Radiological Control Organization. The ISMS is a process to ensure work is performed safely by identifying and assessing hazards associated with specific activities, and implementing barriers and controls for these hazards prior to authorization and execution of the task (BWXT 2003b). Specific GWPP activities are reviewed and controlled through the ISMS with specific job hazard analyses. The GWPP Manager has responsibility for the preparation of required ISMS submittals for specific tasks and coordinating appropriate reviews and approvals. Additionally, the GWPP Manager has responsibility for $\mathrm{H} \& \mathrm{~S}$ incident or accident reporting and coordinating responses to such events through the appropriate organizations.

\subsection{QUALITY ASSURANCE}

Quality assurance for the GWPP is the responsibility of the GWPP Manager. Primary responsibilities for QA are:

- The preparation, maintenance, and implementation of the GWPP Quality Program Plan (QPP) for applicable programmatic elements.

- Provide the GWPP staff with guidance and assistance in meeting programmatic or element quality objectives.

- Nonconformance reporting and corrective action tracking.

- Use an audit tracking system to monitor progress in addressing program deficiencies which have been identified internally or externally.

- Provide assistance with quality reviews of programs, projects, or documents.

\subsection{SAMPLING AND ANALYSIS}

Sampling and analysis of groundwater for the GWPP are implemented by the GWPP Sampling and Analysis Coordinator (see Section 4.1.2), who provides technical direction to the ACO Program Manager and the sampling technicians and/or their supervisor. The ACO Program Manager is the designated laboratory representative responsible for assisting with the preparation and implementation of the annual SAP for the GWPP (and any addenda to the SAP); assuring established analytical procedures are followed; consulting with analytical personnel in development and incorporation of new analytical procedures; providing technical and administrative support to the GWPP; and interacting with the GWPP data management subcontractor to provide electronic data deliverables and help prepare a sample tracking report. Sampling field support for the GWPP is obtained through the ACO Sampling and Environmental Support Department, and from the ECD Environmental Sampling Services Section. 


\subsection{PROCUREMENT}

Procurement of subcontract services (e.g., drilling, technical, reporting, data management) and materials for the GWPP are handled by direct interaction with the BWXT Acquisition and Asset Management Department with support from the ES\&H Division Finance Officer. All procurement for the Y-12 GWPP are conducted following established DOE and BWXT corporate procedures and practices.

\subsection{DATA MANAGEMENT}

The management of groundwater related data at Y-12 is the responsibility of the GWPP Manager. A wide variety of information is collected and maintained. Internally, the GWPP maintains the GIMS which is a system of computer applications which stores hydrogeologic information on such activities as well construction and maintenance, water levels, sampling and analysis, water quality data reporting, and records management. The Y-12 Technical Computing Department supports the GWPP in maintaining and enhancing GIMS capabilities. Analytical data on water quality samples are managed utilizing the GWPP Analytical Data Management System (ADMS). Management of the ADMS is the responsibility of the GWPP ADMS team under contract to BWXT. The ADMS team is comprised of database professionals that report to the GWPP Manager and Technical Coordinator. The primary responsibilities of the ADMS team are to:

- Design, update, and maintain the ADMS for data collected and analyzed during implementation of DOE Order 450.1 surveillance and exit-pathway monitoring activities.

- Assist in the implementation, update, and modification of the Y-12 Data Management Plan.

- Track sampling and data transfer activities relative to the schedules in the annual SAP for the GWPP and report this information to the GWPP Manager and the ACO Program Manager.

- Implement data verification to ensure that the data quality objectives established by the GWPP are met.

- Establish and implement procedures for database security, backup, data entry, tracking, processing, and verification.

- Respond to hard copy and electronic data transfer requests made to and approved by the GWPP Manager.

- Generate summary statistics for Y-12 groundwater monitoring data included in the annual ORR Annual Site Environmental Report. 


\subsection{DATA VALIDATION AND EVALUATION}

Statistical analysis, validation, and evaluation of groundwater data are currently conducted by a subcontractor to BWXT. The subcontractor coordinates statistical analysis activities with the GWPP Manager and personnel responsible for hydrogeological interpretation (see Section 4.12). Primary responsibilities in the area of statistical analysis are to:

- Generate summary statistics and graphical presentations in response to requests made or approved by the GWPP manager.

- Assure the quality of the statistical analyses performed.

- Assure the quality of chemical analyses through data evaluation and validation in accordance with the GWPP Data Management Plan and interface with the ACO Project Manager.

- Compilation of the annual GWMR for the GWPP (see Section 4.8.1.1) and the Monitoring Data Evaluation Compendium (see Section 4.8.1.2).

\subsection{REPORTING AND NOTIFICATION}

The GWPP Manager is responsible for all routine and non-routine reporting of DOE Order 450.1 surveillance and exit-pathway monitoring to Y-12 management, DOE, and regulatory agencies in a prompt and efficient manner. Routine reporting consists of the preparation of annual documents which provide information on activities performed and data obtained by the GWPP. Non-routine reporting consists of any intermittent or unscheduled information and/or any unusual events or occurrences, regardless of significance or severity.

\subsubsection{Routine Reporting}

Routine Reports are prepared to meet the requirements of DOE Orders and are typically on an annual cycle. These reports are prepared to provide information pertaining to the specific requirements of the DOE Orders such as baseline monitoring, regulatory compliance, and evaluation of known and potential contaminant sources through surveillance and exit pathway monitoring.

\subsubsection{Groundwater Monitoring Data Reports}

Groundwater quality and water-level monitoring results obtained at Y-12 during a CY are documented in the annual GWMR issued by the GWPP. The annual GWMR contains the monitoring data obtained in each of the hydrogeologic regimes at Y-12 (Bear Creek Regime, Chestnut Ridge Regime, and East Fork Regime) and includes data obtained by the GWPP and data obtained by other organizations (e.g., RCRA monitoring data obtained by the WRRP). Accordingly, the GWMR functions as a single-source reference for monitoring data used to demonstrate compliance with applicable requirements of DOE Order 450.1. Beginning in CY 2003, the scope 
of the annual GWMR expanded to incorporate: (1) a summary of monitoring results for applicable sampling locations that indicate contamination from one or more of the primary inorganic, organic, and radiological contaminants at Y-12 and (2) recommendations for changes in GWPP monitoring procedures and protocols.

\subsubsection{Monitoring Data Evaluation Compendium}

As noted in Section 3.1.6, the GWPP initiated preparation of the MDEC in CY 2003 to replace the annual GWDER as the forum used to address and document Y-12 compliance with specific DOE Order 450.1 requirements for Surveillance Monitoring and Exit-Pathway Monitoring (see Section 2.3.1). Updated annually, the MDEC serves as a single-source reference for each sampling location granted "active" status by the GWPP, as defined in the GWPP Monitoring Optimization Plan (see Section 5.5), and provides a comprehensive summary and evaluation of the monitoring results for each applicable sampling location, including:

- well construction details;

- $\quad$ water-level characteristics and hydrologic testing results (if applicable);

- the sampling history, including the current governing regulatory program(s);

- $\quad$ the sampling method(s);

- field measurements and laboratory analytes;

- results that do not meet DQO criteria;

- geochemical characteristics;

- the presence of inorganic, organic, and radiological contaminants; and

- long-term contaminant concentration trends.

\subsubsection{Oak Ridge Reservation Annual Site Environmental Report}

The GWPP contributes groundwater information to the ORR Annual Site Environmental Report. The annual GWMR and MDEC are utilized to provide this information.

\subsubsection{Well Inspection and Maintenance Reports}

A report is issued annually to document the monitoring well inspection and maintenance activities performed at Y-12 by the GWPP. Inspection and maintenance of the Y-12 monitoring well network is critical to ensure collection of representative groundwater samples and to maximize the effective lifespan of each monitoring well. 


\subsubsection{Non-Routine Reporting}

As with routine reports, non-routine reports are prepared to meet the requirements of DOE Orders but are not submitted on a set schedule. These reports may be informational in nature, and, due to the infrequency of activities, may not be required on an annual or other routine bases (e.g., well installation summary reports, well P\&A summary reports, the Y-12 subsurface database, investigation/study reports, etc.). Some reports may be required to provide prompt information to management, DOE, and/or environmental agencies in order to address significant environmental compliance issues. In the event that a significant environmental compliance issue occurs, notification will be performed in compliance with BWXT procedure Y14-192, "Occurrence Notification and Reporting."

One computer application of the GIMS is the Environmental Quality Control and Analysis System. This automated system provides weekly reports on water quality results from the ACO to the GWPP staff. These reports provide GWPP staff the ability to evaluate analytical results from the laboratory in a timely manner and act upon this information as required to protect groundwater resources and meet DOE Order and BWXT reporting requirements.

\subsection{RECORDKEEPING AND DOCUMENT CONTROL}

Recordkeeping and document control for the GWPP are the ultimate responsibility of the GWPP Manager. These responsibilities include:

- Generation and archiving of reports and documents to meet regulatory and/or DOE Order requirements.

- Acquisition of appropriate reference and guidance documents and materials.

- Maintenance of a record tracking system and records center.

Control and tracking of element records and documents are included in the individual project plans (see Section 5.0), and coordination of the recordkeeping and documentation is the responsibility of the GWPP Manager.

\subsection{HYDROGEOLOGICAL INTERPRETATION}

Hydrogeological interpretation of groundwater data and statistical results are the responsibility of the GWPP Manager. Primary responsibilities of the GWPP Manager for hydrogeological interpretations are:

- Preparation of technical reports and correspondence.

- Serving as technical consultant to other programs.

- Identification of needs for hydrogeological subcontractor services. 
- Serving as technical contact for subcontracts.

- Special groundwater and hydrogeologic studies.

\subsection{ENGINEERING AND WELL INSTALLATION}

Engineering services for the GWPP are provided by the BWXT Engineering Organization. Services provided upon request from the GWPP Manager include subcontractor services, drawing searches and preparation, utility and geotechnical information, and any required engineering support for drilling services and well installations, such as surveying services. The GWPP Manager has the responsibility to acquire necessary permits for drilling operations, such as excavation, welding, and work safety permits. The GWPP Technical Coordinator directs on-site supervision of drilling and well installation subcontractors, and functions as a project health and safety officer for drilling or geotechnical field activities.

\subsection{TECHNICAL SUPPORT}

The GWPP is responsible for providing technical and data resources to Y-12 organizations and other ORR organizations as requested. 


\subsection{PROJECT PLANS}

This section provides a summary of the various project plans that guide the implementation of the GWPP management strategy described in Section 3. References for the actual plans are cited within the text.

\subsection{HEALTH AND SAFETY PLAN}

The GWPP Organization implements the BWXT ISMS, which was established to protect the worker, the public and the environment. The ISMS is utilized to: (1) ensure that any activity is defined; (2) hazards (potential and real) are identified; (3) controls are implemented to eliminate or control identified hazards; (4) the work is performed under established controls; and (5) post-action feedback is provided to continuously improve activity safety and performance. The GWPP has implemented the ISMS (i.e., completed job hazard identifications and job hazard analyses) for specific field operations (i.e., groundwater and surface water sampling, monitoring well inspection and maintenance, and water level measurement) routinely performed by BWXT employees. New activities identified will undergo the ISMS process in accordance with BWXT Program Description Y15-635PD and any and all indicated subordinate procedures. Subcontractors are also subject to the ISMS to the extent that such requirements are incorporated into contractor documents and health and safety plans.

\subsection{QUALITY ASSURANCE PLAN}

A comprehensive QPP is the current principal QA guidance source for the GWPP Organization (Science Applications International Corporation [SAIC] 1994). The QPP plan identifies key personnel responsible for implementation and provides for the planning and accomplishment of activities affecting quality assurance. Specifically, the plan addresses procurement procedures, document control, sample identification and control, qualification requirements for analytical and sampling techniques, equipment calibration requirements, corrective actions, and quality assurance records and audits. Although the GWPP Manager is ultimately responsible for the implementation of QA requirements and for assuring and verifying the quality of the GWPP, each Coordinator is responsible for day-to-day QA/QC requirements of their assigned program elements.

To supplement the existing QPP, technical and administrative procedures have been developed. These procedures provide requirements, instructions, and information concerning environmental data gathering, sampling and analysis.

\subsection{MONITORING WELL INSTALLATION PLAN}

The GWPP Monitoring Well Installation Plan (SAIC 1997) provides technical guidance and procedures for the design, installation, construction, and development of monitoring wells at Y-12, along with the associated documentation and requirements for the handling and disposal of drill 
cuttings and well development fluids in accordance with applicable regulations, DOE Orders, and BWXT corporate policy.

The GWPP Manager is responsible for the installation of monitoring wells in compliance with the Monitoring Well Installation Plan. The GWPP Manager is responsible for obtaining adequate funding for well installation purposes and for initiating work releases to obtain geological and drilling subcontractor services and engineering support for well installations. The GWPP Technical Coordinator organizes and directs drilling operations in the field. An on-site geologist (a registered geologist or registered professional geologist in the State of Tennessee) ensures that the drilling subcontractor complies with technical specifications and procedures of this plan for well installations and documents all well construction and development information. All monitoring well installation, construction, and development information is documented in a report issued by the GWPP.

\subsection{SAMPLING AND ANALYSIS PLAN}

As noted in Section 3.1.1, a standard protocol of the GWPP at Y-12 is the preparation of a comprehensive SAP for each CY. Maintained and implemented by the GWPP Sampling and Analysis Coordinator, the SAP identifies the sampling locations, sampling frequency, sampling sequence, analytical parameters, and QA/QC sampling planned by the GWPP Organization for each CY. Any modifications or changes to these monitoring activities are documented in addenda to the SAP issued by the GWPP Manager.

\subsection{MONITORING OPTIMIZATION PLAN}

The Y-12 MOP describes the technical approach implemented by the GWPP to focus available resources on the monitoring wells that provide the most useful hydrologic and water-quality monitoring data (BWXT 2003c). The technical approach is based on the GWPP status designation for each well in the Y-12 well network. Under this approach, wells granted "active" status are prioritized by the GWPP for hydrologic monitoring and/or groundwater sampling, whereas wells granted "inactive" status are not used for either purpose. The status designation also determines the frequency at which the GWPP will inspect applicable wells, the scope of these well inspections, and extent of any maintenance actions initiated by the GWPP.

\subsection{LABORATORY QUALITY ASSURANCE PLAN}

A laboratory Quality Assurance Plan (QAP) for the ACO issued in May 2003 (BWXT 2003d) describes the field and laboratory QA utilized for the purposes of the GWPP at Y-12. This QAP describes techniques and systems necessary to obtaining uniform and reliable analytical results from groundwater monitoring locations. The QAP provides a standard for all activities involved in collecting and analyzing samples, and in reporting data. Specifically, it contains procedures and directions that are to be followed for sample collection, sample preservation and handling, chain of custody, sample analysis, QA/QC, and data quality evaluation. 
The Y-12 ACO Program Manager assures that the DQOs of the GWPP are met. The ACO Program Manager also tracks analytical costs and notifies the GWPP Manager of any potential cost increases or potential overruns.

\subsection{DATA MANAGEMENT PLAN}

The Data Management Plan for the GWPP(BWXT 2003e) is implemented by the ADMS Team with support from data evaluators, the ACO Program Manager, the GWPP Technical Coordinator, and the GWPP Manager. Data are tracked between the ACO Program Manager and the ADMS Team utilizing software in conjunction with tracking reports. Analytical data are transferred electronically upon completion of analysis of samples from an administrative well group. Weekly tracking reports and field sampling sheets are sent from the ACO Program Manager to the GWPP Sampling and Analysis Coordinator. Electronic and hard copies of data are sent to the ADMS Team and the data evaluators and the statistical subcontractor as administrative well groups are completed. The Data Management Plan is modified as required and changes are documented by the ADMS Team.

\subsection{WELL PLUGGING AND ABANDONMENT PLAN}

The GWPP Monitoring Well Plugging and Abandonment Plan (LMES 1997) contains the technical guidance and procedures for the removal of obsolete or irreparably damaged monitoring wells at Y-12. Wells of similar construction materials and design are grouped together, and a single procedure was developed for each group of wells. The objective of each procedure is to prevent fluid migration into or between formations containing groundwater, to remove any well materials that may have been in contact with contaminated material or groundwater, and to minimize the amount of waste materials generated during the plugging and abandonment procedure.

The GWPP Manager is responsible for generating an inventory of wells considered for plugging and abandonment, reviewing the plan annually, and issuing addenda as needed. The GWPP Manager designates wells to be plugged and abandoned through coordination with managers of other monitoring programs and/or operations, review of well inspection and maintenance reports, and review of the annual GWMR and corresponding GWDER for each hydrogeologic regime. Well inspection and maintenance reports identify wells that are damaged or unusable. Managers of other Y-12 organizations identify wells that must be removed because of construction or site closure activities. The GWPP Manager is also responsible for developing a schedule of P\&A activities, obtaining subcontractor services for the plugging and abandonment, obtaining engineering support for field operations oversight, and ensuring that the subcontractor complies with the plugging and abandonment procedures. Reports documenting plugging and abandonment activities are issued by the GWPP.

\subsection{WELL INSPECTION AND MAINTENANCE PLAN}

The GWPP Well Inspection and Maintenance Plan (LMES 1996) provides the technical guidance and procedures for the inspection and maintenance of monitoring wells at Y-12 to extend the life of the wells and to ensure that they yield representative water levels and water-quality samples. The 
plan includes a checklist of items to be inspected (such as condition of concrete pads, hasps, caps, locks, and protective posts; the measured depth of the monitored interval compared to the constructed depth; and well access considerations), standardized forms for inspection and requests for maintenance, and a schedule for well inspections. As wells are inspected and problems requiring attention are identified, a schedule to repair or rehabilitate wells is developed and updated through the year. Additionally, problems reported by sampling teams to the GWPP Sampling and Analysis Coordinator are added to the repair/rehabilitation schedule. 


\subsection{REFERENCES}

Bechtel National, Inc., 1984a. "Interim Report on Bear Creek Valley Oil Landfarm Geology and Hydrogeology." Y/SUB/84-47974C/1.

Bechtel National, Inc., 1984b. "Geologic and Hydrologic Data for Bear Creek Valley Burial Grounds A and B.” Y/SUB/84-47974C/2.

Bechtel National, Inc., 1984c. "The Geology and Hydrogeology of Bear Creek Valley Waste Disposal Areas A and B." Y/SUB/84-47974C/3.

Bechtel National, Inc., 1984d. "Interim Report on the Geology and Hydrogeology of the Southern and Western Perimeter to the Burial Grounds and the Interior Portions of Bear Creek Valley Waste Disposal Areas Environmental Field Studies." Y/SUB/84-47974C/4.

Bechtel National, Inc., 1985. "Geologic Data on Twenty Monitoring Wells Installed in Bear Creek Valley in September and October 1984." Y/SUB/84-477974C12.

BWXT Y-12 L.L.C. 2002. "Calendar Year 2001 Groundwater Monitoring Data Evaluation Report for the U.S. Department of Energy Y-12 National Security Complex, Oak Ridge, Tennessee." Y/SUB/02-012529/2.

BWXT Y-12 L.L.C. 2003a. "Updated Subsurface Data Base for Bear Creek Valley, Chestnut Ridge, and Parts of Bethel Valley on the U.S. Department of Energy Oak Ridge Reservation." Y/TS-881/R4.

BWXT Y-12 L.L.C. 2003b. “BWXT Y-12 Integrated Safety Management System.” Y15-635PD.

BWXT Y-12 L.L.C. 2003c. "Y-12 Groundwater Protection Program Monitoring Optimization Plan for Groundwater Monitoring Wells at the U.S. Department of Energy Y-12 National Security Complex, Oak Ridge, Tennessee.” Y/SUB/03021559/2.

BWXT Y-12 L.L.C. 2003d. "Quality Assurance Plan for the Analytical Chemistry Organizations." (Rev. L) Y/P65-9006.

BWXT Y-12 L.L.C. 2003e. "Y-12 Plant Groundwater Protection Program Data Management Plan." (Rev. 1) Y/SUB/03-013288/1.

Duratek Federal Services, Inc. 2003. "Environmental Monitoring Plan for the Environmental Management Waste Management Facility."

Geraghty \& Miller, Inc., 1985a. "Evaluation of Monitoring Well Network in the Bear Creek Valley Waste Disposal Area." Y/SUB/85-00206C/1.

Geraghty \& Miller, Inc., 1985b. "Preliminary Findings of the 1984-85 Investigations of Contamination at the S-3 Ponds." Y/SUB/8400206/3. 
Geraghty \& Miller, Inc., 1986. "Phase IV Monitor-Well Drilling Program in the Bear Creek Valley Waste Disposal Area." Y/SUB/85-00206C/8.

Geraghty \& Miller, Inc., 1987. "Preliminary Evaluation of Hydrogeologic and Water Quality Data from Phase IV Wells Located in Bear Creek Valley Waste Disposal Area for the Period Summer 1985 - September 1986." Y/SUB/87-00206C/9.

Geraghty \& Miller, Inc., 1990. "Comprehensive Groundwater Monitoring Plan for the Department of Energy Y-12 Plant, Oak Ridge, Tennessee.” Y/SUB/90-00206C/5.

Haase, C. S., G. A. Gillis, and H. L. King, 1987a. "Fiscal Year 1985 Groundwater Investigation Drilling Program at the Y-12 Plant, Oak Ridge, Tennessee." ORNL/TM-9999.

Haase, C. S., H. L. King, and G. A. Gillis, 1987b. "Preliminary Hydrological and Hydrochemical Assessment of the Beta-4 Security Pit, the Kerr Hollow Quarry, the Ravine Disposal, the Rogers Quarry, and the United Nuclear Sites at the Y-12 Plant, Oak Ridge, Tennessee." Y/TS-272.

Haase, C. S., H. L. King, and G. A. Gillis, 1987c. "Preliminary Hydrological and Hydrochemical Assessment of the Chestnut Ridge Security Pits, the Chestnut Ridge Sludge Disposal Basin, and the New Hope Pond Sites at the Y-12 Plant, Oak Ridge, Tennessee." Y/TS-272.

King, H. L. and C. S. Haase, 1987. "Subsurface-Controlled Geological Maps for the Oak Ridge Y-12 Plant and Portions of Bear Creek Valley.” ORNL/TM-10112.

King, H. L. and C. S. Haase, 1989. "Results and Preliminary Interpretation of Hydrogeologic Packer Testing in Core Holes CH-157, GW-131, and GW-132 through GW-135 at the Oak Ridge Y-12 Plant." Y/TS-495.

King, H.L. and C.S. Haase. 1990. "Oak Ridge Y-12 Plant Groundwater Protection Program Management Plan.” Y/TS-633.

Law Engineering, 1983. "Results of Groundwater Monitoring Studies.” Y/SUB/83-47936/1.

Lee, R. R. and R. H. Ketelle, 1989. “Geology of the West Bear Creek Site.” ORNL/TM-0887.

Lockheed Martin Energy Systems, Inc., 1996. "Monitoring Well Inspection and Maintenance Plan, Y-12 Plant, Oak Ridge, Tennessee.” Y/TS-1215.

Lockheed Martin Energy Systems, Inc., 1997. "Monitoring Well Plugging and Abandonment Plan, Y-12 Plant, Oak Ridge Tennessee.” Y/TS-1611.

Pritz, P.M., 1983. "Master Monitoring Plan for Groundwaters and Surface Waters. Oak Ridge Y-12 Plant." Unnumbered Martin Marietta Energy Systems, Inc. Document.

Rothschild, E. R., R. R. Turner, S. H. Stow, M. A. Bogle, L. K. Hyder, O. M. Sealand, and H. J. Wyrick, 1984. "Investigation of Subsurface Mercury at the Oak Ridge Y-12 Plant." ORNL/TM-9092. 
Science Applications International Corporation. 1994. “Groundwater Protection Program Quality Program Plan.” Y/SUB/94-99069C/Y13/1.

Science Applications International Corporation. 1997. "Monitoring Well Installation Plan for the Department of Energy Y-12 Plant, Oak Ridge, Tennessee.” Y/SUB/97-99069C(Y27)/1.

U.S. Department of Energy, 1994. "Oak Ridge Reservation Site Management Plan for the Environmental Restoration Program.” DOE/OR-1001/R3.

U.S. Department of Energy, 1997. "Report on the Remedial Investigation of Bear Creek Valley at the Oak Ridge Y-12 Plant, Oak Ridge, Tennessee.” DOE/OR-01-1455/V1 \& D2.

U.S. Department of Energy, 2001. "Remedial Design Workplan for the Phase I Activities in Bear Creek Valley at the Oak Ridge Y-12 Plant, Oak Ridge, Tennessee." DOE/OR-01-1760 \& D3.

U.S. Department of Energy, 2003. "Environmental Monitoring Plan for the Oak Ridge Reservation.” DOE/OR-1066/R5.

U.S. Environmental Protection Agency, 1992. "RCRA Groundwater Monitoring: Draft Technical Guidance.” EPA/530-R-93-001. 


\section{DISTRIBUTION}

U.S. DEPARTMENT OF ENERGY

J.D. Darby, DOE-EM

J.P. Donnelly, DOE-NNSA

BWXT Y-12, L.L.C.

ENVIRONMENTAL COMPLIANCE

DEPARTMENT

S.M. Field

C.C. Hill

S.B. Jones

J.E. Powell

E.R. Schultz

L.O. Vaughan

GWPP-File (2)

EC Document Center

BWXT Y-12, L.L.C.

ANALYTICAL CHEMISTRY

ORGANIZATION

D.D. Altom

YDCC-RC

Y-12 Records Services (Electronic copyOSTI)

\section{BECHTEL JACOBS COMPANY LLC}

H.L. King

L.M. Sims (2)

E. Trujillo

File-EMEF-DMC

SCIENCE APPLICATIONS

INTERNATIONAL CORPORATION

W.K. Jago

D.L. Smith

J.L. Vance

UT-BATTELLE, LLC

J.F. Hughes

R.S. Loffman

D.B. Watson

ELVADO ENVIRONMENTAL LLC.

T.R. Harrison

J.R. Walker

TENNESSEE DEPARTMENT OF ENVIRONMENT AND CONSERVATION DOE OVERSIGHT DIVISION

D. Gilmore (3) 